\title{
Post-ruminal supplies of glucose and casein, but not acetate, stimulate milk protein synthesis in dairy cows through differential effects on mammary metabolism
}

\author{
M. A. C. Danes, ${ }^{1 *} \odot$ M. D. Hanigan, ${ }^{2} \odot$ S. I. Arriola Apelo, ${ }^{3} \odot$ J. D. L. Dias, ${ }^{1}{ }^{\oplus}$ M. A. Wattiaux, ${ }^{3} \oplus$ \\ and G. A. Broderick ${ }^{4}$ () \\ ${ }^{1}$ Department of Animal Science, University of Lavras, Lavras, 37200, Brazil \\ ${ }^{2}$ Department of Dairy Science, Virginia Tech, Blacksburg 24061 \\ ${ }^{3}$ Department of Dairy Science, University of Wisconsin, Madison 53706 \\ ${ }^{4}$ Broderick Nutrition and Research LLC, Madison, WI 53705
}

\section{ABSTRACT}

Amino acids and glucose have been shown to regulate protein synthesis in the mammary gland through their effects on cellular signaling pathways. Acetate might also have an effect on protein synthesis via the AMPactivated kinase signaling pathway, because it is the main energy source for the mammary secretory cell. Thus, the objective of this experiment was to evaluate the effects of casein and energy-yielding nutrients (acetate and glucose), and their combination, on performance and mammary metabolism. Six multiparous Holstein cows, averaging $49 \mathrm{~kg}$ of milk/d, were used in a $6 \times 6$ Latin square design with 14-d periods. Cows were fed to $100 \%$ National Research Council requirements for metabolizable protein (MP) and energy (ME) for $9 \mathrm{~d}$, after which they were feed-restricted for $5 \mathrm{~d}$ to $85 \%$ of their individual ad libitum intake and then abomasally infused with 1 of 6 treatments. Treatments were acetate $(A)$, glucose $(G)$, each at $5 \%$ of ad libitum ME intake, casein (C) at $15 \%$ of ad libitum MP intake, $\mathrm{A}+\mathrm{C}, \mathrm{G}+\mathrm{C}$, or a saline solution (negative control). Casein infused alone increased milk protein yield numerically, with $25 \%$ recovery of the infused casein in milk protein. Glucose infused alone increased milk and milk protein yield and promoted the highest efficiency of nitrogen utilization (37\%), with an efficiency of MP use for milk protein of $58 \%$. We discovered no effect of treatment on mammary plasma flow, and the increase in milk protein yield with glucose infusion was brought about by greater mammary AA clearance rate. Infusion of casein and glucose together further increased milk protein yield in an additive fashion, and $47 \%$ of the infused casein was recovered in milk protein. Acetate infused alone had no effect on milk protein yield but increased milk fat yield numerically, suggesting that

Received December 19, 2019.

Accepted February 28, 2020.

*Corresponding author: marina.danes@ufla.br the greater amount of acetate taken up by the mammary gland was used for milk fat synthesis. Infusion of acetate and casein together yielded responses similar to those of casein alone. In conclusion, glucose has a major effect on stimulating milk protein synthesis, and the mammary gland has the ability to increase its supply of nutrients to match its synthetic capacity.

Key words: amino acids, abomasal infusions, energy, nitrogen efficiency

\section{INTRODUCTION}

Milk protein synthesis is stimulated by both glucose and EAA supplies to the mammary gland (Hanigan et al., 1998a; Lemosquet et al., 2010). The effect of energy from dietary carbohydrates on milk protein yield is typically explained by increased EAA supply from increased microbial protein outflow due to higher availability of fermentable carbohydrates (Broderick, 2003). However, intravenous infusion of insulin (Mackle et al., 1999) and post-ruminal provision of glucose (Rulquin et al., 2004) and starch (Rius et al., 2010a) have also been found to increase milk protein yield, suggesting a direct effect of carbohydrates on stimulating milk protein synthesis.

The mechanisms by which milk protein synthesis is affected by post-absorptive supplies of both protein and energy from carbohydrates include substrate and regulatory effects at the tissue level. Most current nutritional models approach the relationship between substrates and products within the mammary gland as fixed and proportional. In other words, the models predict component synthesis based on the supply of their main substrate. However, this relationship is not so simple and straightforward. The supply of AA in the abomasum or duodenum has been found to increase lactose yield (Lemosquet et al., 2009a; Doepel and Lapierre, 2010; Galindo et al., 2011), and the supply of glucose post-ruminally or propionate in the rumen 
increase milk protein yield (Vik-Mo et al., 1974; Rigout et al., 2003; Rulquin et al., 2004; Raggio et al., 2006; Toerien et al., 2010). Substrates act as building blocks for their respective milk components but can also function as energy providers upon oxidation or contribute to the pool of carbon used to synthesize other milk components.

Nutrients can also function, directly or indirectly, through hormones, as signaling molecules altering transduction pathways that regulate the rates of protein synthesis. It has been demonstrated in vitro that EAA, glucose, and insulin can stimulate milk protein synthesis independently (Appuhamy et al., 2011, 2012; Arriola Apelo et al., 2014; Yoder et al., 2020), challenging the limiting nutrient theory incorporated in every nutrient requirement system for lactating dairy cows. Substrate-independent stimulation of milk protein synthesis could increase post-absorptive AA efficiency (Mackle et al., 1999; Castro et al., 2016) and reduce manure $\mathrm{N}$ content. These independent responses must be understood so that the most effective and efficient mix of AA and energy supply can be provided.

Although the effect of glucose or glucogenic nutrients on milk protein yield has been the focus of in vivo studies (Lemosquet et al., 2010; Rius et al., 2010b), the effect of acetate specifically on milk protein synthesis has received little attention. Acetate is the main energy source for mammary cells (Hanigan and Baldwin, 1994) and has the potential to stimulate the mammalian target of rapamycin complex 1 (mTORC1) signaling through AMP-activated kinase (AMPK; Appuhamy et al., 2014). In fact, intravenous infusions of acetate tended to increase milk protein yield in early-lactation goats fed a protein-restricted diet $(80 \%$ of requirements), compared with a saline infusion (Safayi and Nielsen, 2013). Likewise, Maas et al. (1995) observed a trend for increased milk protein production when acetate was infused arterially. However, others have not observed responses in milk protein yield with ruminal acetate infusions (Sheperd and Combs, 1998).

Therefore, the hypothesis of this study was that milk protein synthesis is stimulated independently by acetate, glucose, and casein. The objectives of the experiment were to evaluate production responses, especially milk protein yield, to the individual nutrients and to their combination, and to link these responses to mammary metabolism.

\section{MATERIALS AND METHODS}

\section{Experimental Procedure}

Animal care and experimental procedures were approved by the Animal Care and Use Committee of the
College of Agriculture and Life Science of the University of Wisconsin-Madison. Six multiparous Holstein cows fitted with permanent 10-cm rumen cannulas (Bar Diamond Inc., Parma, ID), averaging (mean \pm SD) at the beginning of the trial $133 \pm 28$ DIM, $49.8 \pm 5.6$ $\mathrm{kg}$ of milk/d, and $715 \pm 45 \mathrm{~kg}$ of BW were used in a Latin square design with 14-d periods. Cows were housed in tiestalls with free access to water. All cows were injected with bST (500 mg of Posilac; Elanco Animal Health, Greenfield, IN) every other week, on the fifth day of each experimental period. Cows were randomly assigned to 1 of 6 treatment sequences in a $6 \times 6$ Latin square balanced for carryover effects. All cows were fed a common diet throughout the trial, and treatments were infused into the abomasum. Each 14-d experimental period included $9 \mathrm{~d}$ of feed offered ad libitum, followed by $5 \mathrm{~d}$ of restricted intake $(85 \%$ of ad libitum intake) in combination with the continuous infusions ( $22 \mathrm{~h} / \mathrm{d}$, stopping only for milking). Feed was restricted during the infusion periods to ensure that the infusions did not cause a feed intake reduction and to ensure that the animals consumed most or all of each meal when offered, thus stabilizing absorption patterns. The amount of $15 \%$ was chosen because the combination of the energy contained in the infused nutrients provided approximately $10 \%$ of the energy supply, and thus feed offered plus infusions represented, at most, $95 \%$ of cows' ad libitum intake. In this manner, the treatments examined the response to the nutrients within the normal nutrient supply range rather than on top of the normal supply, as a response may not occur if animals are at their maximum production potential.

The nutrient composition of the main ingredients of the TMR is shown in Table 1, and the dietary ingredient composition and analyzed dietary nutrient composition are shown in Table 2. The diet was formulated to meet $100 \%$ of the NRC (2001) ME requirements and 93.5\% of the MP requirements. During the first $9 \mathrm{~d}$ of each period, cows were fed ad libitum, once daily at about $0800 \mathrm{~h}$, allowing for 5 to $10 \%$ orts. During the last $5 \mathrm{~d}$, feed offered to each cow was restricted to $85 \%$ of her respective ad libitum intake (averaged from the previous $6 \mathrm{~d}$ of the adaptation period) and provided in 6 equal-sized meals at 0000, 0400, 0800, 1200, 1600, and $2000 \mathrm{~h}$, to minimize postprandial variation of blood metabolite concentrations.

The infusion solutions were formulated based on each cow's ad libitum energy and protein intake for each period and consisted of (1) acetate (A) infused in an amount equivalent to $5 \%$ of ad libitum ME intake; (2) glucose $(\mathbf{G})$ infused in an amount equivalent to $5 \%$ of ad libitum ME intake; (3) casein $(\mathbf{C})$ infused in an amount equivalent to $15 \%$ of ad libitum MP intake; (4) A + C (AC); (5) G + C (GC); and (6) saline solution (S) 
Table 1. Nutrient composition of principal dietary ingredients ${ }^{1}$

\begin{tabular}{lcccc}
\hline Item & AS & CS & WCS & Conc. \\
\hline DM, \% & 34.2 & 39.1 & 93.3 & 90.6 \\
CP, \% of DM & 20.0 & 5.7 & 24.3 & 21.1 \\
NDF, \% of DM & 49.5 & 44.5 & 46.5 & 14.8 \\
ADF, \% of DM & 38.3 & 24.4 & 31.8 & 7.8 \\
NDICP, \% of DM & 2.9 & 0.9 & 3.3 & 3.1 \\
ADICP, \% of DM & 0.93 & 0.13 & 1.53 & 0.65 \\
Ash, \% of DM & 10.8 & 4.1 & 4.6 & 10.8 \\
AA, \% of CP & & & & \\
Ala & 9.6 & 7.1 & 3.7 & 4.9 \\
Arg & 1.5 & 2.2 & 10.3 & 6.4 \\
Asp & 8.7 & 6.4 & 8.7 & 9.2 \\
Glu & 4.1 & 11.5 & 17.9 & 17.6 \\
His & 1.2 & 1.8 & 2.5 & 2.6 \\
Ile & 3.9 & 3.2 & 2.9 & 4.1 \\
Leu & 6.1 & 8.3 & 5.4 & 8.2 \\
Lys & 3.4 & 2.9 & 4.2 & 5.4 \\
Met & 1.2 & 1.6 & 1.4 & 1.6 \\
Phe & 3.8 & 4.0 & 5.0 & 4.7 \\
Pro & 4.2 & 6.4 & 3.6 & 6.3 \\
Ser & 2.6 & 3.8 & 4.1 & 4.7 \\
Thr & 2.6 & 3.5 & 3.1 & 3.9 \\
Val & 5.1 & 4.4 & 4.1 & 4.9 \\
\hline
\end{tabular}

${ }^{1} \mathrm{AS}=$ alfalfa silage; $\mathrm{CS}=$ corn silage; $\mathrm{WCS}=$ whole cottonseed, with lint; Conc. $=$ concentrate mix containing $(\mathrm{DM}$ basis $) 49.5 \%$ dry ground corn grain, $14.0 \%$ solvent-extracted soybean meal, $15.6 \%$ canola meal, $4.8 \%$ expeller soybean meal, $5.6 \%$ soybean hulls, $3.8 \%$ energy booster, $2.3 \%$ limestone, $0.8 \%$ sodium bicarbonate, $0.4 \%$ potassium carbonate, $1.0 \%$ calcium monophosphate, $0.6 \%$ magnesium oxide, $0.4 \%$ potassium magnesium sulfate, $0.7 \%$ trace mineral premix + selenium, $0.4 \%$ vitamin ADE premix.

${ }^{2} \mathrm{NDICP}=$ neutral detergent insoluble CP.

${ }^{3} \mathrm{ADICP}=$ acid detergent insoluble $\mathrm{CP}$.

as a negative control. Metabolizable energy contents of acetate and glucose used in the calculations were 209 and $673 \mathrm{kcal} / \mathrm{mol}$, respectively. The casein source was sodium caseinate, which contained $98.6 \%$ casein, considered 95\% digestible (Hanigan et al., 2004). Acetate solutions were prepared from equal proportions (molar basis) of sodium acetate and acetic acid. Sodium chloride was used to equalize the $\mathrm{Na}$ content (mean of 196 $\mathrm{g} / \mathrm{d}$ ) of all infusion solutions. The mean nutrient composition of the solutions is shown in Table 3. Solutions were prepared daily with warm tap water to the final volume of $12 \mathrm{~L} / \mathrm{d}$ and continuously infused into the abomasum via the rumen cannula, using a peristaltic pump as described by Gressley et al. (2006). Acetate solutions had a $\mathrm{pH}$ of 4.7 and thus had to be infused separately from the casein, using a dual infusion line to avoid casein precipitation in the container and lines.

Amounts of feed offered and refused were recorded daily. Weekly samples of the silages, whole cottonseeds, concentrate mix, and TMR were taken, and DM contents were determined by oven-drying at $60^{\circ} \mathrm{C}$ for $48 \mathrm{~h}$. The DM values for TMR were used to calculate DMI. Samples of the ingredients from wk 2 of each period were ground to pass a 1-mm screen (Wiley mill, Arthur H. Thomas, Philadelphia, PA) and analyzed for DM
Table 2. Composition of experimental diet

\begin{tabular}{lc}
\hline Item & \% of DM \\
\hline Ingredient & \\
Alfalfa silage & 15.0 \\
Corn silage & 35.0 \\
Dry ground corn grain & 23.7 \\
SSBM $^{1}$ & 6.7 \\
Canola meal $^{2}$ & 7.5 \\
SBM, expeller & 2.3 \\
Soyhulls & 2.7 \\
Cottonseed, whole with lint & 2.2 \\
Prilled fatty acids & 1.8 \\
Calcium carbonate & 1.1 \\
Sodium bicarbonate & 0.40 \\
Potassium carbonate & 0.20 \\
Calcium phosphate & 0.50 \\
Magnesium oxide & 0.27 \\
K and Mg sulfate & 0.20 \\
Trace mineral premix + Se $^{4}$ & 0.34 \\
Vitamin ADE & 0.20 \\
Nutrient composition & \\
CP & 15.6 \\
NDF & 31.1 \\
ADF & 18.7 \\
EE & 5.3 \\
NFC & Starch
\end{tabular}

${ }^{1} \mathrm{SSBM}=$ solvent-extracted soybean meal.

${ }^{2}$ Soybean meal; SoyPlus (Landus Cooperative, Ames, IA).

${ }^{3}$ Energy Booster 100 (Milk Specialties, Eden Prairie, MN).

${ }^{4}$ Provided (per $\mathrm{kg}$ of diet DM): $1 \mathrm{mg}$ of Co, $5 \mathrm{mg}$ of $\mathrm{Cu}, 0.3 \mathrm{mg}$ of I, $12.3 \mathrm{mg}$ of $\mathrm{Fe}, 0.01 \mathrm{mg}$ of $\mathrm{Mg}, 0.2 \mathrm{mg}$ of Se, $19 \mathrm{mg}$ of $\mathrm{Zn}$.

${ }^{5}$ Provided (per kg of diet DM): 203,478 IU of vitamin A, 67,826 IU of vitamin $\mathrm{D}_{3}, 678 \mathrm{IU}$ of vitamin $\mathrm{E}$.

${ }^{6} \mathrm{EE}=$ ether extract, calculated using NRC (2001) table values for \% fat of each ingredient.

${ }^{7} \mathrm{NFC}=100-\%$ of $\mathrm{NDF}-[\%$ of $\mathrm{CP}-(6.25 \times \%$ of NDIN $) / 100]-$ $\%$ of fat $-\%$ of ash.

${ }^{8}$ Calculated from diet formulation, assuming 1.2, 30, 72, 1.5, 1, 1.5, 1.5 , and $0 \%$ starch for alfalfa silage, corn silage, dry ground corn grain, solvent-extracted soybean meal, canola meal, expeller soybean meal, soybean hulls, and cottonseed whole with lint, respectively.

at $105^{\circ} \mathrm{C}$ (method $\left.967.03 ; \mathrm{AOAC}, 1990\right)$, total $\mathrm{N}$ (Leco 2000 N Analyzer; Leco Instruments, Inc., St. Joseph, $\mathrm{MI}$ ), ash, and OM (AOAC, 1980), and sequentially for NDF, ADF, and ADIN (Van Soest, et al., 1991) using

Table 3. Mean infused nutrients $(\mathrm{g} / \mathrm{d})$ for each treatment ${ }^{1}$

\begin{tabular}{lrrrrrr}
\hline Item & $\mathrm{S}$ & $\mathrm{A}$ & \multicolumn{1}{c}{$\mathrm{G}$} & $\mathrm{C}$ & $\mathrm{AC}$ & $\mathrm{GC}$ \\
\hline Acetate & 0 & 913 & 0 & 0 & 935 & 0 \\
Glucose & 0 & 0 & 817 & 0 & 0 & 830 \\
Casein $^{2}$ & 0 & 0 & 0 & 404 & 423 & 404 \\
NaCl $^{2}$ & 494 & 48 & 494 & 479 & 21 & 479 \\
\hline
\end{tabular}

${ }^{1} \mathrm{~S}=$ abomasal infusion of saline solution; $\mathrm{A}=$ abomasal infusion of acetate, at a daily rate of $5 \%$ of ad libitum ME intake; $\mathrm{G}=$ abomasal infusion of glucose, at a daily rate of $5 \%$ of ad libitum ME intake; $\mathrm{C}=$ abomasal infusion of casein, at a daily rate of $15 \%$ of ad libitum MP intake; $\mathrm{AC}=$ abomasal infusion of $\mathrm{A}+\mathrm{C} ; \mathrm{GC}=$ infusion of $\mathrm{G}+\mathrm{C}$.

${ }^{2}$ Included in the solutions to equalize the Na supply across all treatments $(196 \mathrm{~g} / \mathrm{d})$. 
heat-stable amylase and sodium sulfite (Hintz et al., 1996), and for NDIN omitting $\alpha$-amylase and $\mathrm{Na}_{2} \mathrm{SO}_{3}$ during extraction (Licitra et al., 1996).

Cows were milked twice daily at 0530 and $1730 \mathrm{~h}$ and milk weights recorded. Milk samples were collected from both a.m. and p.m. milkings on d 8 to 13 of each experimental period, preserved with 2-bromo-2-nitropropane-1,3-diol, and analyzed for fat, true protein, lactose, SNF, and MUN content by infrared spectroscopy (AgSource Laboratory, Verona, WI) using a Foss FT6000 [Foss North America Inc., Eden Prairie, MN; AOAC (1990) method no. 972.16]. Daily milk composition was computed as weighted means based on the a.m. and p.m. samples and milk yields. Net energy for lactation secreted in milk was calculated as described by Tyrrell and Reid (1965):

$$
\begin{gathered}
\mathrm{NE}_{\mathrm{L}}-\text { milk, Mcal } / \mathrm{d}=\text { milk, } \mathrm{kg} / \mathrm{d} \\
\times[(0.0929 \times \text { fat }, \%)+(0.0563 \times \text { true protein, \% }) \\
+(0.0395 \times \text { lactose }, \%)] .
\end{gathered}
$$

Energy-corrected milk yield $(\mathrm{kg} / \mathrm{d})$ was calculated by dividing $\mathrm{NE}_{\mathrm{L}}$-milk by a constant energy content of milk of $0.749 \mathrm{Mcal} / \mathrm{kg}$ (Krause et al., 2003). The efficiency of $\mathrm{N}$ use (ENU) was calculated from milk true protein:

$$
\begin{gathered}
\text { ENU, } \mathrm{g} / \mathrm{g}=(\text { milk true protein, } \mathrm{g} / \mathrm{d} \div 6.38) / \\
(\mathrm{N} \text { intake }+\mathrm{N} \text { infused, } \mathrm{g} / \mathrm{d})
\end{gathered}
$$

Blood samples were taken on d 13 of each period into heparinized test tubes, from a coccygeal vessel and the subcutaneous abdominal vein, at approximately $0630 \mathrm{~h}$ (immediately after a.m. milking), 1000, 1330, and 1700 h (immediately before p.m. milking). The composition of coccygeal blood was assumed to be equivalent to that of arterial blood (Emery et al., 1965). Blood was refrigerated until centrifugation $\left(1,500 \times g, 4^{\circ} \mathrm{C}, 15\right.$ min), and the resulting plasma was stored at $-20^{\circ} \mathrm{C}$ until analysis. Samples of arterial plasma were composited by cow within period for plasma urea nitrogen (PUN) analysis (Broderick and Clayton, 1997). The remaining analyses were run on individual plasma samples. Plasma was analyzed for glucose (Karkalas, 1985), BHB (kit no. 2440, Stanbio Laboratory, Boerne, TX), and acetate (kit no. EOAC-100, BioAssay Systems, Hayward, CA). Plasma AA concentration was analyzed by isotope dilution (Calder et al., 1999) using a gas chromatograph coupled with a mass spectrometer (Shimadzu Corp, single quadrupole GCMS-QP2010; Kyoto, Japan).

Mammary plasma flow was estimated according to the Fick principle, using Phe + Tyr, assuming a 3.5\% contribution from blood-borne proteins (Cant et al., 1993):

$$
\begin{gathered}
\text { Plasma flow }(\mathrm{L} / \mathrm{h})=(\text { milk Phe }+ \text { Tyr }, \mu \mathrm{mol} / \mathrm{h} \\
\times 0.965) \div(\text { arterial Phe }+ \text { Tyr }- \text { venous Phe } \\
+ \text { Tyr, } \mu \text { mol } / \mathrm{L})
\end{gathered}
$$

where milk Phe + Tyr was the milk protein yield from the sampling period multiplied by the milk AA composition reported by Lapierre et al. (2012). Milk AA composition was not analyzed because we did not expect the treatments to alter it.

Net fluxes of metabolites across the mammary gland (mammary net flux, $\mu \mathrm{mol} / \mathrm{h}$ ) were calculated for each cow within period as follows:

$$
\begin{gathered}
\text { Mammary net flux, } \mu \mathrm{mol} / \mathrm{h}= \\
(\text { arterial }- \text { venous, } \mu \mathrm{mol} / \mathrm{L}) \times \text { plasma flow, } \mathrm{L} / \mathrm{h},
\end{gathered}
$$

where arterial - venous was the mean metabolite concentration for the sampling period.

Ratios of mammary uptake to milk output were calculated for each AA thus:

Uptake:Output, $\mu \mathrm{mol} / \mu \mathrm{mol}=$ mammary AA uptake,

$$
\mu \mathrm{mol} / \mathrm{h} \div \text { (milk AA secretion, } \mu \mathrm{mol} / \mathrm{h}) \text {. }
$$

For milk AA, a $3.5 \%$ contribution from blood-borne proteins (Cant et al., 1993) was taken into account by multiplying the AA secretion $(\mu \mathrm{mol} / \mathrm{h})$ by 0.965 .

Clearance rate represents the apparent affinity of the mammary gland for plasma metabolites. These were computed for each metabolite by rearrangement of the equation described by Hanigan et al. (1998b):

$$
\begin{aligned}
& \text { Clearance rate, } \mathrm{L} / \mathrm{h}=\text { mammary uptake, } \\
& \qquad \mu \mathrm{mol} / \mathrm{h} \div \text { venous, } \mu \mathrm{mol} / \mathrm{L}
\end{aligned}
$$

For all the AA-related variables, AA were evaluated individually, and the sum of all AA, all EAA, and all NEAA were calculated on a nitrogen basis.

\section{Statistical Analysis}

All data were analyzed using the Mixed procedure of SAS 9.4 (SAS Institute Inc., Cary, NC; 2013). The effects of treatment on performance and PUN were assessed for a Latin square design with cow $\times$ period as the experimental unit. The model included the fixed effects of treatment, period, and their interaction, and the random effect of cow. Degrees of freedom were 
calculated using the Kenward-Roger option. Interactions were removed from the model when they were not significant $(P>0.15)$, but all main effects were left in the model regardless of significance. One cow went off feed during data collection in period 3 , and her data for that period were discarded. Another cow presented with severe clinical mastitis during the last period and was removed from the trial. Both cows were on the AC treatment, leaving 4 observations for the $\mathrm{AC}$ treatment and 6 for the other treatments.

The model used for plasma metabolite concentrations (except PUN) included treatment, period, time of collection, and interaction of treatment $\times$ time of collection as fixed effects, and cow as a random effect. The interaction of treatment $\times$ time was not significant $(P>0.15)$ for any variable and was removed from the model. The covariance structure used for the repeated measures was chosen based on the Akaike information criterion. Data were considered outliers and excluded from the data set when a Student's residual higher than 3 or lower than -3 was detected. Least squares means with the highest standard error of the mean are reported for all data. Significance was declared at $P \leq$ 0.05 , and Tukey-adjusted $P$-values were used to compare least squares means.

\section{RESULTS}

\section{Animal Performance and Plasma Metabolites}

Energy, protein, and EAA balances estimated using the NRC model (NRC, 2001) with the observed inputs (treatment means for milk yields, milk composition, BW, and DMI) are presented in Table 4. Despite the $15 \%$ feed restriction during collection periods, the estimated deficiencies (amount supplied vs. amount required) vary from 4.6 to $14.6 \%$ for energy and from 5.8 to $16.9 \%$ for protein, according to the milk production response to each treatment. When energy and protein supplies from infusion solutions were considered, the total supplies of energy (Mcal/d) were 95, 101, 93, 93,100 , and $96 \%$ of requirements for treatments S, A, G, C, AC, and GC, respectively. Likewise, total MP supplies $(\mathrm{g} / \mathrm{d})$ were $93,94,83,106,110$, and $98 \%$ of requirements for treatments $\mathrm{S}, \mathrm{A}, \mathrm{G}, \mathrm{C}, \mathrm{AC}$, and $\mathrm{GC}$, respectively. Total digestible EAA supply for the treatments with casein infusion were computed using the actual average digestible casein inputs for each treatment and casein EAA composition as reported by Lapierre et al. (2012). None of the treatments achieved ideal Met content (\% of MP) or Lys to Met ratios (2.3\% and 3:1, respectively; NRC, 2001).

Performance data are shown in Table 5. Acetate alone did not promote any changes in milk yield, lac- tose yield and content, or milk protein yield or content relative to the negative control $(P>0.05)$, but increased fat content compared with $\mathrm{S}, \mathrm{G}, \mathrm{C}$, and GC $(P<0.05)$. Fat content also was greater for $\mathrm{AC}$ than for the 2 treatments with glucose infusions $(P<0.05)$. Glucose, infused alone or in combination with casein, increased milk yield by $14 \%$ and milk protein yield by $13 \%$ relative to $\mathrm{S}$ and $\mathrm{A}(P<0.05)$; the effects of $\mathrm{AC}$ were intermediate and did not differ from the other treatments $(P>0.05)$. Cows receiving $\mathrm{C}$ produced less milk than cows infused with $\mathrm{G}(P<0.05)$, but we found no difference in milk protein yield between these 2 treatments. Concentration of MUN was greater for AC than for all other treatments $(P<0.05)$ with a $45 \%$ increase relative to the lowest value for $\mathrm{G}$. Glucose infusion alone decreased MUN relative to $\mathrm{C}, \mathrm{AC}$, and $\mathrm{S}(P$ $<0.05$ ), which reflected the greater nitrogen utilization efficiency for the $\mathrm{G}$ treatment $(P<0.05)$ relative to the other treatments.

Treatment did not affect PUN $(P>0.10)$, although the numeric changes mimicked MUN concentrations for the extreme values, especially the $44 \%$ increase for AC relative to $\mathrm{G}$ (Table 6). Arterial glucose concentration was increased by $\mathrm{C}$ relative to $\mathrm{G}$ and $\mathrm{S}(P<0.05)$; the other treatments showed intermediate results. Conversely, C reduced BHB arterial concentration compared with $\mathrm{A}, \mathrm{AC}$, and $\mathrm{S}(P<0.05)$, whereas treatment A increased BHB relative to $\mathrm{G}$ and $\mathrm{GC}(P<0.05$; Table 6). Plasma acetate was increased by $34 \%$ in the 2 treatments in which acetate was infused (A and AC), relative to the other 4 treatments $(P<0.05)$.

Arterial concentrations of most of the AA were affected by treatment (Table 6). The infusion of GC increased arterial concentration of total AA nitrogen (AA-N) relative to the 3 treatments that did not receive any casein infusion (A, G, and $\mathrm{S} ; P<0.05)$; C and $\mathrm{AC}$ were intermediate but still higher than $\mathrm{A}(P$ $<0.05)$. Likewise, arterial concentration of EAA-N was higher for the casein infusions: $\mathrm{AC}$ was higher than $\mathrm{A}$, $\mathrm{G}$, and $\mathrm{S}(P<0.05)$, whereas $\mathrm{C}$ and $\mathrm{GC}$ were higher than $\mathrm{G}(P<0.05)$. Conversely, arterial concentration of NEAA-N was not elevated for AC, which was smaller than GC $(P<0.05)$ but still higher than A $(P<0.05)$. In fact, $\mathrm{A}$ had lower NEAA-N arterial concentration than all the other treatments $(P<0.05)$, except for $\mathrm{AC}$.

Among the individual AA, Lys, His, Met, Pro, and Tyr followed the same pattern of response as total $\mathrm{AA}$, and their arterial concentrations were increased by casein infusions relative to $\mathrm{A}, \mathrm{G}$, and $\mathrm{S}(P<0.05$ for all comparisons except $\mathrm{C}$ and $\mathrm{AC}$ vs. $\mathrm{S}$ for His and Met, C vs. S for Lys, C and AC vs. G for Met, and $\mathrm{AC}$ vs. $\mathrm{S}$ for Tyr). Interestingly, even though arterial concentrations of EAA-N were smallest for glucose in- 
Table 4. NRC (2001) estimates of energy, protein, and amino acid supplies and balances based on actual inputs and amounts of nutrients infused $^{1}$

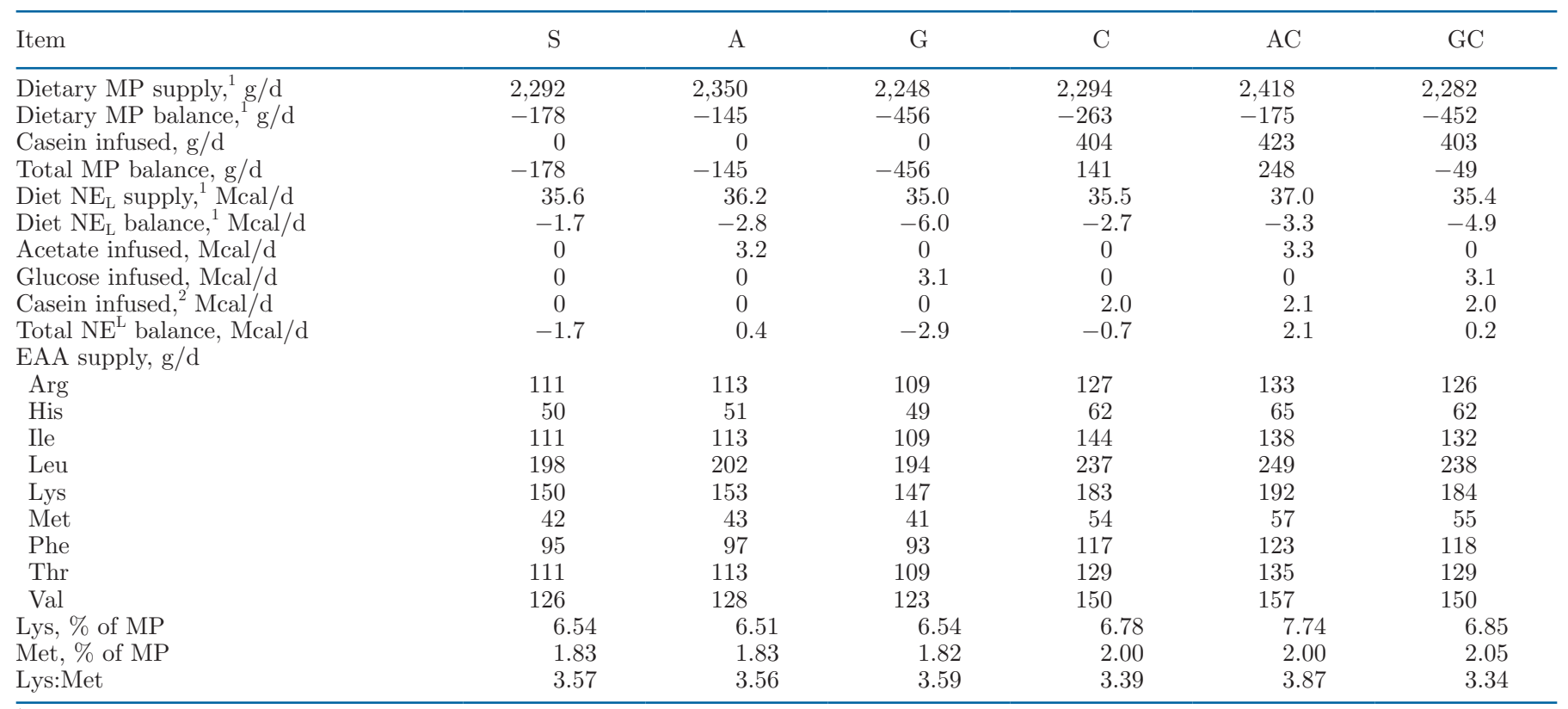

${ }^{1}$ NRC (2001) estimates using ingredient analyzed nutrient composition and treatment means for DMI, milk yield and composition, and BW. S = abomasal infusion of saline solution; $\mathrm{A}=$ abomasal infusion of acetate, at a daily rate of $5 \%$ of ad libitum ME intake; $\mathrm{G}=$ abomasal infusion of glucose, at a daily rate of $5 \%$ of ad libitum ME intake; $\mathrm{C}=$ abomasal infusion of casein, at a daily rate of $15 \%$ of ad libitum MP intake; AC $=$ abomasal infusion of $\mathrm{A}+\mathrm{C} ; \mathrm{GC}=$ infusion of $\mathrm{G}+\mathrm{C}$.

${ }^{2}$ Casein energy value calculated based on $5 \mathrm{kcal} / \mathrm{g}$.

fusions, some NEAA were increased on this treatment to the same level as C and AC (Ala, Asn, and Ser, $P$ $<0.05)$, but Gly arterial concentration was higher for $\mathrm{G}$ than for $\mathrm{C}$, AC, and A $(P<0.05)$. Furthermore, glucose infusion alone or in combination with casein increased arterial concentrations of Thr and Gln to the highest levels among the treatments. Acetate infused alone reduced the arterial concentration of most AA, whereas the negative control overall was in between the 2 energy-only infusions and the 3 treatments that contained casein

\section{Mammary Metabolism}

Mammary plasma flow was not affected by treatment $(P=0.78$, Table 7$)$. However, clearance rates of glucose and many AA were altered in response to the infusions (Table 7). Glucose clearance rate was greater for A than

Table 5. Effects of abomasal infusions of acetate, glucose, casein, and combinations on cow performance ${ }^{1}$

\begin{tabular}{|c|c|c|c|c|c|c|c|c|}
\hline Item & S & $\mathrm{A}$ & G & $\mathrm{C}$ & $\mathrm{AC}$ & GC & SEM & $P$-value \\
\hline Milk yield, $\mathrm{kg} / \mathrm{d}$ & $36.4^{\mathrm{c}}$ & $37.1^{\mathrm{c}}$ & $42.8^{\mathrm{a}}$ & $37.8^{\mathrm{bc}}$ & $39.2^{\mathrm{abc}}$ & $42.3^{\mathrm{ab}}$ & 2.4 & 0.03 \\
\hline $\mathrm{ECM}, \mathrm{kg} / \mathrm{d}$ & 34.4 & 36.9 & 39.2 & 36.7 & 38.9 & 38.5 & 2.5 & 0.31 \\
\hline Fat yield, $\mathrm{kg} / \mathrm{d}$ & 1.41 & 1.58 & 1.55 & 1.42 & 1.65 & 1.51 & 0.14 & 0.32 \\
\hline Protein, \% & 3.12 & 3.08 & 3.04 & 3.16 & 3.05 & 3.11 & 0.08 & 0.27 \\
\hline Protein yield, $\mathrm{kg} / \mathrm{d}$ & $1.13^{\mathrm{b}}$ & $1.14^{\mathrm{b}}$ & $1.30^{\mathrm{a}}$ & $1.23^{\mathrm{ab}}$ & $1.21^{\mathrm{ab}}$ & $1.32^{\mathrm{a}}$ & 0.09 & 0.05 \\
\hline $\mathrm{ENU}^{3} \%$ & $32.7^{\mathrm{b}}$ & $32.3^{\mathrm{b}}$ & $38.8^{\mathrm{a}}$ & $32.4^{\mathrm{b}}$ & $27.2^{\mathrm{c}}$ & $32.9^{\mathrm{b}}$ & 2.4 & $<0.01$ \\
\hline
\end{tabular}

${ }^{\mathrm{a}-\mathrm{c}}$ Means within a row followed by different letters differ at $P<0.05$.

${ }^{1} \mathrm{~S}=$ abomasal infusion of saline solution; $\mathrm{A}=$ abomasal infusion of acetate, at a daily rate of $5 \%$ of ad libitum ME intake; $\mathrm{G}=$ abomasal infusion of glucose, at a daily rate of $5 \%$ of ad libitum ME intake; $\mathrm{C}=$ abomasal infusion of casein, at a daily rate of $15 \%$ of ad libitum MP intake; $\mathrm{AC}=$ abomasal infusion of $\mathrm{A}+\mathrm{C} ; \mathrm{GC}=$ infusion of $\mathrm{G}+\mathrm{C}$.

${ }^{2} \mathrm{DMI}$ without accounting for the infusates.

${ }^{3} \mathrm{ENU}=$ efficiency of nitrogen use $(\mathrm{g} / \mathrm{g})$ : (milk true protein, $\left.\mathrm{g} / \mathrm{d} \div 6.38\right) /(\mathrm{N}$ intake $+\mathrm{N}$ infused, $\mathrm{g} / \mathrm{d})$. 
Table 6. Effects of abomasal infusions of acetate, glucose, casein, and combinations on arterial concentration of urea N (PUN), glucose, acetate, $\mathrm{BHB}$, and $\mathrm{AA}^{1}$

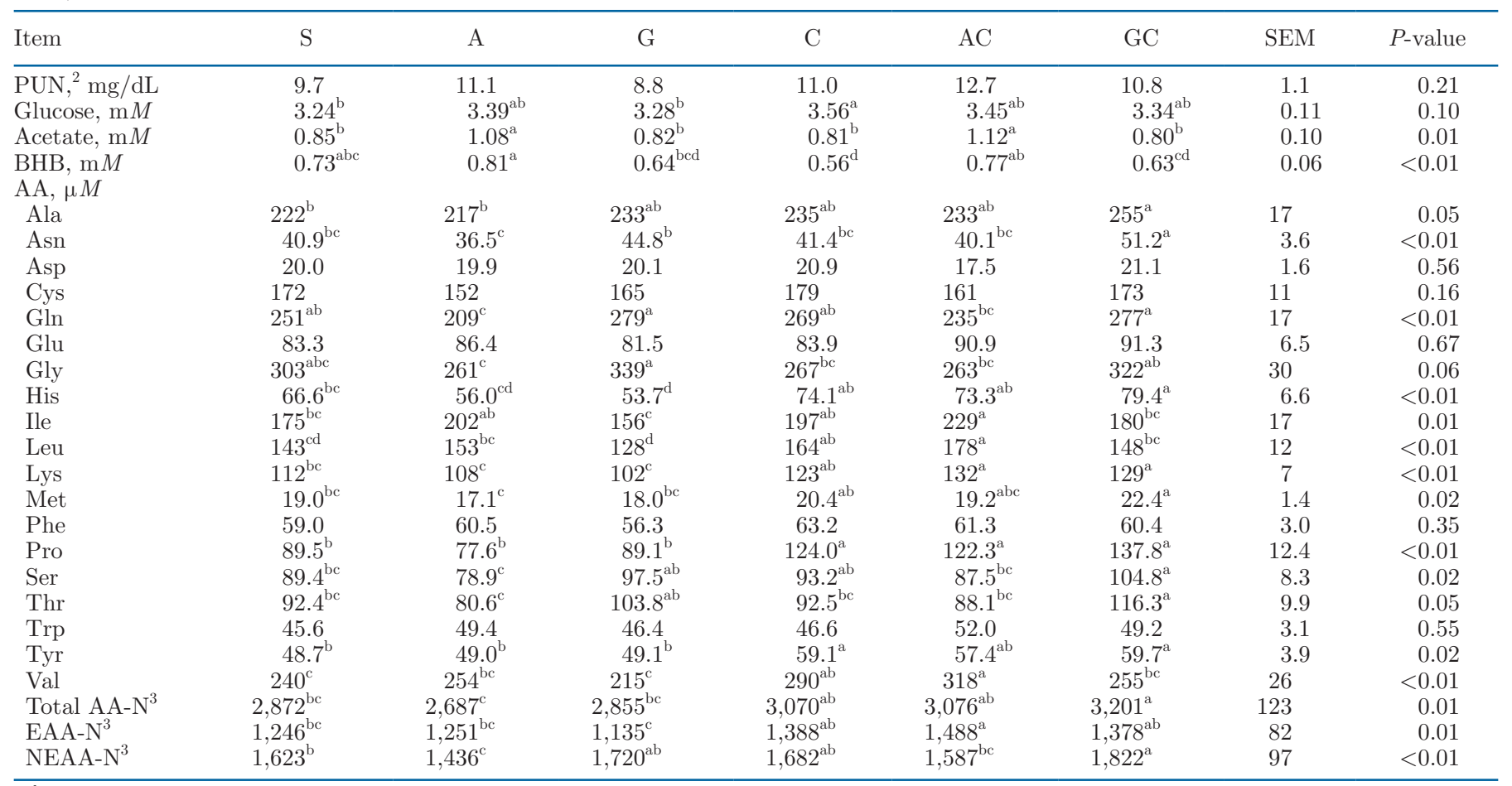

${ }^{\mathrm{a}-\mathrm{d}}$ Means within a row followed by different letters differ at $P<0.05$.

${ }^{1} \mathrm{~S}=$ abomasal infusion of saline solution; $\mathrm{A}=$ abomasal infusion of acetate, at a daily rate of $5 \%$ of ad libitum ME intake; $\mathrm{G}=$ abomasal infusion of glucose, at a daily rate of $5 \%$ of ad libitum ME intake; $\mathrm{C}=$ abomasal infusion of casein, at a daily rate of $15 \%$ of ad libitum MP intake; $\mathrm{AC}=$ abomasal infusion of $\mathrm{A}+\mathrm{C} ; \mathrm{GC}=$ infusion of $\mathrm{G}+\mathrm{C}$.

${ }^{2} \mathrm{PUN}=$ plasma urea nitrogen.

${ }^{3}$ Total AA-N = sum of all analyzed AA, on N basis; EAA-N = sum of His, Ile, Leu, Lys, Met, Phe, Thr, Trp, and Val, on N basis; NEAA-N = sum of Ala, Asn, Asp, Asn, Cys, Glu, Gln, Gly, Pro, Ser, and Tyr, on N basis.

for $\mathrm{G}, \mathrm{C}$, and $\mathrm{S}(P<0.05)$, and it was greater for $\mathrm{GC}$ than for $\mathrm{C}(P<0.05)$. Clearance rates of acetate, BHB, total AA-N, and NEAA-N were not affected by treatment $(P>0.10)$. Conversely, treatment $\mathrm{G}$ increased the EAA-N clearance rate relative to $\mathrm{A}, \mathrm{C}, \mathrm{AC}$, and $\mathrm{S}(P<0.05)$, and $\mathrm{GC}$ was intermediate. Likewise, $\mathrm{G}$ increased clearance rates for His (greater than all the other treatments; $P<0.05$ ), Ile, and Leu (relative to all the other treatments except GC; $P<0.05$ ), Met (relative to $\mathrm{C}$ and $\mathrm{GC} ; P<0.05$ ), Lys (relative to $\mathrm{C}, \mathrm{AC}$, and S; $P<0.05$ ), Val (relative to A, C, and AC; $P<$ 0.05), Pro (relative to C, AC, and GC; $P<0.05$ ), and Tyr (relative to $\mathrm{C}, \mathrm{AC}$, and $\mathrm{S} ; P<0.05$ ). The clearance rate of Met was also increased by the infusion of acetate alone, compared with $\mathrm{C}$ and $\mathrm{GC}(P<0.05)$. Moreover, the Asp clearance rate was greater for GC than for A and $\mathrm{C}(P<0.05)$. Overall, $\mathrm{C}$ and $\mathrm{AC}$ had the smallest clearance rates for most $\mathrm{AA}$.

Mammary uptake (Table 8) is a consequence of extracellular concentrations and clearance rate, the former being affected by blood flow and clearance. Mammary glucose uptake was greater for A than G, C, AC, and
$\mathrm{S}(P<0.05)$, and greater for $\mathrm{GC}$ than $\mathrm{C}$ and $\mathrm{S}(P<$ $0.05)$. Mammary uptake of BHB and acetate were not affected by treatment $(P>0.10)$, even though acetate uptake for treatment $\mathrm{C}$ was numerically decreased by $37 \%$ relative to the average of the 2 acetate infusions and BHB uptake was numerically decreased by $30 \%$ relative to the average of all the other treatments. Mammary uptake of total AA-N was not affected by treatment $(P$ $=0.13$ ), although the numeric differences responded in a manner similar to the response of milk protein yield from the milking directly after blood sampling. Treatment GC increased mammary uptake of EAA-N compared with $\mathrm{A}, \mathrm{C}$, and $\mathrm{S}(P<0.05)$. On the other hand, uptake of NEAA-N was increased by $\mathrm{G}$ relative to A, C, and AC $(P<0.05)$. Mammary uptakes of Lys and Ile were increased by GC compared with A, G, C, and $\mathrm{S}(P<0.05)$, and $\mathrm{AC}$ was intermediate. Threonine mammary uptake was greater for GC than for A, C, and $\mathrm{S}(P<0.05)$. Among the NEAA, GC increased mammary uptake of Pro (relative to A, C, and S; $P<$ 0.05), Asn (relative to all the other treatments but G; $P<0.05$ ), and Ala (relative to A and AC; $P<0.05$ ). 
Table 7. Effects of abomasal infusions of acetate, glucose, casein, and combinations on mammary plasma flow (MPF) and clearance rates of glucose, acetate, BHB, and AA $(\mathrm{L} / \mathrm{h})^{1}$

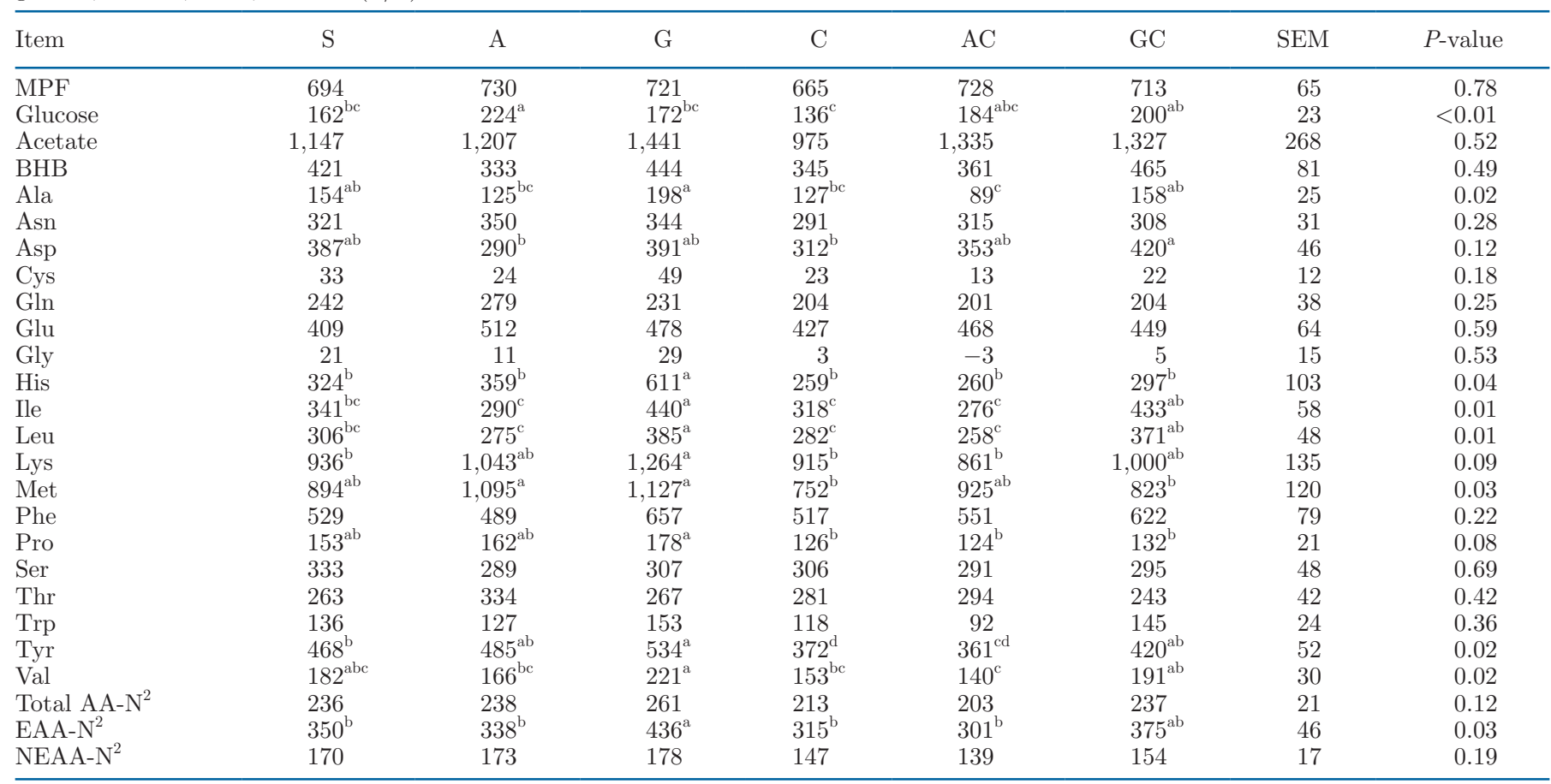

${ }^{\mathrm{a}-\mathrm{d}}$ Means within a row followed by different letters differ at $P<0.05$.

${ }^{1} \mathrm{~S}=$ abomasal infusion of saline solution; $\mathrm{A}=$ abomasal infusion of acetate, at a daily rate of $5 \%$ of ad libitum ME intake; $\mathrm{G}=$ abomasal infusion of glucose, at a daily rate of $5 \%$ of ad libitum ME intake; $\mathrm{C}=$ abomasal infusion of casein, at a daily rate of $15 \%$ of ad libitum MP intake; $\mathrm{AC}=$ abomasal infusion of $\mathrm{A}+\mathrm{C} ; \mathrm{GC}=$ infusion of $\mathrm{G}+\mathrm{C}$.

${ }^{2}$ Total AA-N = sum of all analyzed AA, on $\mathrm{N}$ basis; EAA-N = sum of His, Ile, Leu, Lys, Met, Phe, Thr, Trp, and Val, on N basis; NEAA-N = sum of Ala, Asn, Asp, Asn, Cys, Glu, Gln, Gly, Pro, Ser, and Tyr, on N basis.

Treatment G also increased Ala, Asn, and Ser mammary uptake compared with $\mathrm{A}, \mathrm{C}$, and $\mathrm{AC}(P<0.05)$. Mammary uptake of Gly was only different from $0(P$ $<0.05)$ for $\mathrm{G}$ and $\mathrm{S}$.

Milk protein, milk fat, and lactose yields from the milking immediately after blood sampling are presented in Table 8 to allow comparison with the mammary uptake of the main precursors of milk components. The differences among treatments for milk protein and lactose yields were not as great at this milking as they were for the average of the whole sampling period; thus, treatment effect did not reach significance $(P=0.15$ for protein; $P=0.29$ for lactose). On the other hand, fat yield at this milking was higher for $\mathrm{AC}$ than for $\mathrm{C}$ and $\mathrm{S}(P<0.05)$ and higher for $\mathrm{A}$ than for $\mathrm{C}(P<0.05)$.

Ratios of mammary AA uptake to milk AA output are presented in Table 9. This ratio for total AA-N represents the nitrogen balance across the mammary gland and should be close to unity when all the AA are considered and assuming that contributions from peptides are minimal and estimates of blood flow are unbiased. Total AA-N ratios were greater for $\mathrm{G}$ and $\mathrm{S}$ than for $\mathrm{A}$ and $\mathrm{AC}(P<0.05)$. In addition, total AA-N ratios were less than $1(P<0.10)$ for all treatments except $\mathrm{G}$ and $\mathrm{S}$. Infusion of $\mathrm{AC}$ increased the EAA-N ratio relative to $\mathrm{A}, \mathrm{G}$, and $\mathrm{C}(P<0.05)$; $\mathrm{GC}$ and $\mathrm{S}$ were greater than $\mathrm{A}$ and $\mathrm{G}(P<0.05)$; and $\mathrm{G}$ was smaller than all the other treatments except $\mathrm{A}(P<0.05)$. Conversely, G increased the NEAA-N uptake-to-output ratio compared with all the other treatments except $\mathrm{S}(P<0.05)$, whereas AC had the smallest NEAA-N ratio (smaller than $\mathrm{G}$ and $\mathrm{S}, P<0.05$ ). The ratio of mammary uptake to milk output was greater than $1(P$ $<0.10)$ for all treatments for EAA-N and less than $1(P$ $<0.05$ ) for all treatments for NEAA-N. For individual AA, infusions affected only Ala, Asn, Lys, and Ser ( $P$ $<0.10)$. The Ala ratio was greater for $\mathrm{G}$ than for $\mathrm{A}, \mathrm{C}$, and $\mathrm{AC}(P<0.05)$, and greater for $\mathrm{GC}$ and $\mathrm{S}$ than for $\mathrm{AC}(P<0.05)$. The Asn ratio was greater for $\mathrm{G}$ than for A, $\mathrm{C}$, and $\mathrm{AC}(P<0.05)$, and $\mathrm{GC}$ was greater than $\mathrm{C}$ and $\mathrm{AC}(P<0.05)$. The Ser uptake-to-output ratio was greater for $\mathrm{G}, \mathrm{C}, \mathrm{GC}$, and $\mathrm{S}$ than for $\mathrm{A}$ and $\mathrm{AC}$ $(P<0.05)$. Finally, the Lys ratio was greater for AC than for $\mathrm{A}$ and $\mathrm{G}(P<0.05)$ and greater for $\mathrm{GC}$ and $\mathrm{S}$ than for $\mathrm{G}(P<0.05)$. For all 6 treatments, the ratio of mammary uptake to milk output was less than $1(P<$ 0.10) for Asn, Asp, Glu, Leu, Met, Pro, Ser, Thr, and Tyr. On the other hand, the ratio was greater than 1 
Table 8. Effects of abomasal infusions of acetate, glucose, casein, and combinations on mammary uptake of glucose, acetate, BHB, and AA $(\mathrm{mmol} / \mathrm{h})$ and milk component yields $(\mathrm{g})$ for the milking immediately after blood sampling ${ }^{1}$

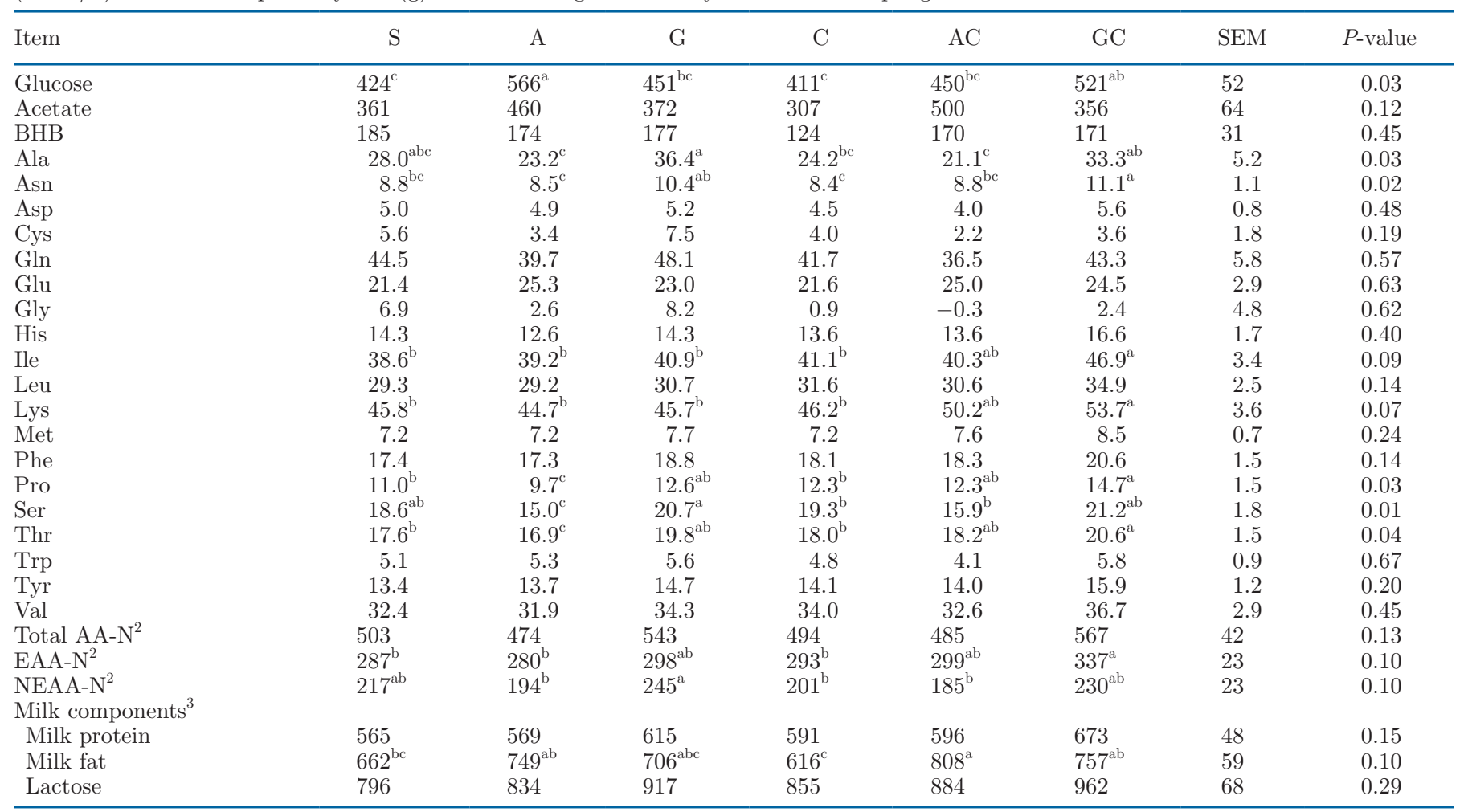

${ }^{\mathrm{a}-\mathrm{c}}$ Means within a row followed by different letters differ at $P<0.05$.

${ }^{1} \mathrm{~S}=$ abomasal infusion of saline solution; $\mathrm{A}=$ abomasal infusion of acetate, at a daily rate of $5 \%$ of ad libitum ME intake; $\mathrm{G}=$ abomasal infusion of glucose, at a daily rate of $5 \%$ of ad libitum ME intake; $\mathrm{C}=$ abomasal infusion of casein, at a daily rate of $15 \%$ of ad libitum MP intake; $\mathrm{AC}=$ abomasal infusion of $\mathrm{A}+\mathrm{C} ; \mathrm{GC}=$ infusion of $\mathrm{G}+\mathrm{C}$.

${ }^{2}$ Total AA-N = sum of all analyzed AA, on N basis; EAA-N = sum of His, Ile, Leu, Lys, Met, Phe, Thr, Trp, and Val, on N basis; NEAA-N = sum of Ala, Asn, Asp, Asn, Cys, Glu, Gln, Gly, Pro, Ser, and Tyr, on N basis.

${ }^{3}$ Milk components produced in the milking immediately after blood sampling.

$(P<0.10)$ for all treatments for His, Ile, Lys, Phe, and Val. For Trp, the ratio was greater than $1(P<0.10)$ for $\mathrm{A}, \mathrm{G}, \mathrm{GC}$, and $\mathrm{S}$, and not different from $1(P>$ 0.10) for $\mathrm{C}$ and $\mathrm{AC}$.

\section{DISCUSSION}

\section{Effects of Casein}

Increases in milk protein yield with post-ruminal casein infusion have been reported in many studies (Broderick et al., 1970; Clark et al., 1977; Whitelaw et al., 1986; Vanhatalo et al., 2003; Raggio et al., 2006). Although we did not observe an effect of casein infusion on milk protein yield in the present study, the numerical increase of $100 \mathrm{~g} / \mathrm{d}$ represented a $25 \%$ recovery of infused casein protein in milk protein relative to the saline control ( $\mathrm{g}$ of milk protein over control divided by $\mathrm{g}$ of casein infused). This was very close to the average recovery of $21 \%$ reported by Hanigan et al. (1998a). Both Whitelaw et al. (1986) and Doepel et al. (2004) observed declining efficiency of MP utilization for milk protein synthesis as supply approached requirement. A maximal marginal efficiency of MP use of about $45 \%$ was reported by both groups when MP supply was well below requirements. Cows on treatment $\mathrm{C}$ were predicted to be $10 \%$ MP deficient before infusion, and the observed $25 \%$ marginal efficiency is consistent with earlier observations but clearly much lower than the $67 \%$ marginal efficiency used in the NRC (2001) model.

One possibility for the lack of a greater response to casein infusion could be that energy supply to the animal, and thus to the mammary cells, was restricted. Protein synthesis is an energy-dependent process (Lobley, 1990) known to be regulated by energy supply (Appuhamy et al., 2014). Lack of response in milk protein yield to abomasal casein infusion was previously observed when cows were $30 \%$ feed restricted (Rius et al., 2010a). Provision of glucose with casein in the present trial yielded a marginal recovery in milk protein of $47 \%$ after adjusting for the $10 \mathrm{~g} / \mathrm{d}$ difference in basal MP intake between GC and $\mathrm{S}$, resulting in 
Table 9. Effects of abomasal infusions of acetate, glucose, casein, and combinations on the ratio of mammary AA uptake to milk AA output ${ }^{1}$

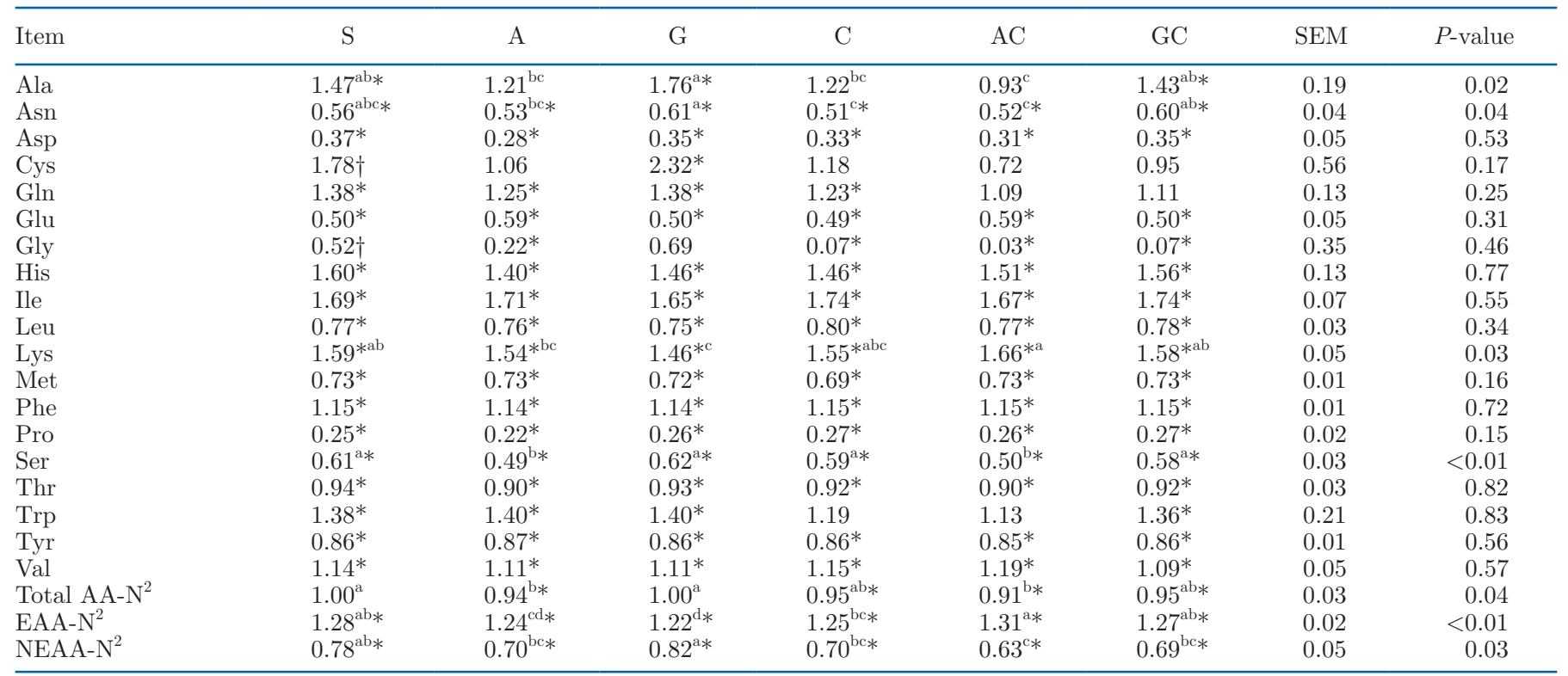

${ }^{\mathrm{a}-\mathrm{d}}$ Means within a row followed by different letters differ at $P<0.05$.

${ }^{1} \mathrm{~S}=$ abomasal infusion of saline solution; $\mathrm{A}=$ abomasal infusion of acetate, at a daily rate of $5 \%$ of ad libitum ME intake; $\mathrm{G}=$ abomasal infusion of glucose, at a daily rate of $5 \%$ of ad libitum ME intake; $\mathrm{C}=$ abomasal infusion of casein, at a daily rate of $15 \%$ of ad libitum MP intake; $\mathrm{AC}=$ abomasal infusion of $\mathrm{A}+\mathrm{C} ; \mathrm{GC}=$ infusion of $\mathrm{G}+\mathrm{C}$.

${ }^{2}$ Total AA-N = sum of all analyzed AA, on N basis; EAA-N = sum of His, Ile, Leu, Lys, Met, Phe, Thr, Trp, and Val, on N basis; NEAA-N = sum of Ala, Asn, Asp, Asn, Cys, Glu, Gln, Gly, Pro, Ser, and Tyr, on N basis.

*Different from $1.0(P<0.05)$.

$\dagger$ Tendency to be different from $1.0(P<0.10)$.

$184 \mathrm{~g} / \mathrm{d}$ greater milk protein yield on GC. Dietary MP supply was similar $(2,294 \mathrm{~g} / \mathrm{d}$ for C vs. $2,282 \mathrm{~g} / \mathrm{d}$ for GC), and amounts of casein infused were identical for $\mathrm{C}$ (404 g/d) and GC (403 g/d). Thus, efficiency of conversion of MP into milk protein should have been similar (Doepel et al., 2004). The almost 90\% increase in MP efficiency upon glucose infusion ( $47 \%$ for GC vs. $25 \%$ for $G$ ) suggests that energy could indeed have limited the response on C. However, when casein was infused with acetate (AC), recovery of the extra protein in milk protein relative to saline (i.e., $423 \mathrm{~g}$ infused plus $126 \mathrm{~g}$ from diet MP supply) was only $13.5 \%$ (45\% decrease vs. C). Although acetate is an important energy source for the mammary cells of ruminant animals (Hanigan and Baldwin, 1994), its infusion should have stimulated response to casein infusion had ATP been limiting protein synthesis.

Compared with the negative control, casein infusion increased arterial glucose concentrations but slightly decreased mammary glucose clearance rate and plasma flow, resulting in a numerically smaller mammary glucose uptake. Mammary uptake of acetate and BHB, both sources of energy to the mammary gland, were also numerically smaller for $\mathrm{C}$, suggesting that the energy demand of mammary cells was not limited by the availability of energy substrates. Increased arterial glucose concentration with casein infusions has been previously reported, with a concomitant increase in net liver glucose flux (Galindo et al., 2011). Increased glucose availability with casein infusion is often associated with increased mammary glucose uptake for lactose and milk yield (Lemosquet et al., 2009a; Galindo et al., 2011). However, glucose uptake did not change, and, accordingly, no increase in lactose or milk yield was observed in the present study for C compared with S.

Another possibility for the limited response to infusion of casein alone could be the limitation of specific EAA, such as Met, because its supply was lower than recommended levels (NRC, 2001). However, this seems unlikely, because all 3 casein treatments increased arterial concentration of most EAA relative to saline. Additionally, AA clearance rates and mammary plasma flow were numerically smaller, resulting in only numeric increases in EAA uptake on $\mathrm{C}$ relative to $\mathrm{S}$. Because the mammary gland has the ability to control local blood flow and clearance rates to match nutrient supply with synthetic demand (Bequette et al., 2000; Cant et al., 2003), the numeric decline in clearance rates for all of EAA suggests that EAA supply increased more than EAA use for milk protein synthesis (Hanigan et al., 
2000; Hundal and Taylor, 2009). If 1 or more EAA had been severely limiting, a large increase in clearance rates would have been expected for those AA on $\mathrm{C}$ relative to S (Bequette et al., 2000).

In the absence of a fully integrated post-absorptive model that represents AA transporter regulation, it is not possible to predict the AA limiting production, but the relative change in clearance rates may be an indication of which AA were more limiting. We calculated the percent change in clearance rates for the EAA between treatments $\mathrm{S}$ and $\mathrm{C}$ and found that the largest relative changes in clearance rates were for His $(20 \%)$, Met (16\%), Trp, (13\%), Tyr (21\%), and Val (16\%). These changes are all modest compared with the 30fold changes observed by Bequette et al. (2000) when a severe His deficiency was imposed. Thus, it seems that the low marginal response to $\mathrm{C}$ simply reflects the response surface given static values for other inputs such as energy substrates and hormonal signals.

Post-ruminal infusions of EAA have increased mammary AA uptake relative to either water or isonitrogenous infusions of urea, Pro, Glu, and Ser, on diets that were both protein deficient (Doepel and Lapierre, 2010; Haque et al., 2015) and protein sufficient (Raggio et al., 2006; Haque et al., 2015). However, in these studies, increased mammary AA uptake was accompanied by increased milk protein output. When no response in milk protein yield was observed to casein infusion, mammary AA uptake was also not increased (Rius et al., 2010a). The numeric difference in milk protein yield between $\mathrm{C}$ and $\mathrm{S}$ in the milking immediately following blood sampling was approximately $55 \mathrm{~g} / \mathrm{d}$ (26 g in $11.3 \mathrm{~h}$ of milking interval), which should have been associated with greater mammary AA uptake. However, plasma Arg was not measured in the present study, which contributes $4 \mathrm{~g}$ of nitrogen per mole of AA taken up, and mammary Arg uptake often increases with casein infusion (Doepel and Lapierre, 2010; Rius et al., 2010a; Haque et al., 2015). In fact, ratios of mammary uptake to milk output for total AA-N were less than 1 for $\mathrm{C}$ but not for $\mathrm{S}$, suggesting that Arg might have contributed more nitrogen on treatment $\mathrm{C}$ than S. Ratios of mammary uptake to milk output were not different between $\mathrm{C}$ and $\mathrm{S}$ for any AA, suggesting no change in intramammary metabolism.

The ratios between mammary AA uptake and milk AA output observed in the present study were close to 1 for total AA-N for all treatments, suggesting a net 0 nitrogen balance across the gland, which is consistent with previous work (Hanigan et al., 2001). However, Met and Leu ratios were less than 1 for all treatments. A deficiency of Met has previously been noted when calculating blood flows using the Fick principle unless
Met is used for the calculation, but Leu uptake is generally found to be more than output in milk (Lapierre et al., 2005). This could be a result of underestimating mammary blood flow or AA contribution from peptides, which was not measured.

In summary, the response of milk protein to casein infusion alone was less than would be predicted by the NRC (2001) model even though the cows were MP deficient according to that model. However, the marginal response was consistent with prior work and with the diminishing-returns response curve of Doepel et al. (2004). The inefficiency of infused casein use was reflected by numeric increases in PUN compared with saline, and AA were likely used for gluconeogenesis given the observed increases in arterial glucose concentration.

\section{Effects of Glucose}

Infusion of glucose had the greatest effects on milk and milk protein yield. When infused alone, glucose increased milk protein yield by $170 \mathrm{~g} / \mathrm{d}$, lactose by 330 $\mathrm{g} / \mathrm{d}$, and milk yield by $6.4 \mathrm{~kg} / \mathrm{d}$ relative to the negative control. This is an impressive response, considering that the cows were in negative MP balance according to NRC (2001). In fact, the efficiency of conversion of NRC-estimated MP to milk protein was $58 \%$ with glucose infusion, compared with $49.5 \%$ for saline. This resulted in an ENU of $36.7 \%$ for the glucose infusion, whereas the other treatments ranged from 30.1 to $33.1 \%$. When glucose was infused along with casein, the response was greater than for separate infusions of casein and glucose, suggesting a partial additive effect. However, due to the extra supply of protein provided by GC, the efficiency of NRC-estimated MP use for milk protein synthesis remained at $49 \%$.

The response to glucose was not surprising, considering several studies have shown positive effects of dietary starch (Broderick, 2003; Rius et al., 2010a; Cantalapiedra-Hijar et al., 2014), post-ruminal glucose supply (Hurtaud et al., 2000; Rigout et al., 2003; Rulquin et al., 2004; Lemosquet et al., 2009a), and ruminal propionate supply (Rigout et al., 2003; Raggio et al., 2006; Lemosquet et al., 2009b) on milk protein yield. However, determining what caused the response is challenging. Infusion of glucose alone did not increase arterial glucose concentration. In contrast, several of the studies reporting increased milk protein with glucogenic nutrients also reported higher arterial glucose concentration (Lemosquet et al., 2009a,b; Rius et al., 2010a). Another common response to supplying glucogenic nutrients is increased mammary plasma flow (Rulquin et al., 2004; Raggio et al., 2006; Rius et al., 2010a). In the present experiment, mammary 
plasma flow was not affected by treatment; however, mammary clearance rate for most AA was highest on the glucose treatment, which allowed for increased mammary AA uptake to account for the extra protein synthesized. The decreased arterial concentrations of most AA observed in this trial accompanying glucose infusions was also reported by Mackle et al. (1999) in a hyperinsulinemic-euglycemic clamp study. The exceptions were the glucogenic AA Asn, Gln, Gly, and Ser, which increased in concentration, suggesting these AA were spared from gluconeogenesis.

Glucose infusion increased clearance rates of all EAA except Thr, which is consistent with stimulation of milk protein synthesis causing reduced intracellular EAA supplies and increased EAA transport activity (Hanigan et al., 2000). The combination of glucose and casein ablated the clearance rate responses, with the exceptions of Ile, Leu, and Phe. However, the increased arterial concentrations allowed the meeting of the increased AA demands by mass action supply alone. Exceptions were Ile, Leu, and Phe, which had arterial concentrations very similar to those on $\mathrm{S}$ and, hence, required continued elevation of the clearance rate to meet tissue demands.

Despite the numerical increase in lactose yield with both glucose treatments ( $\mathrm{G}$ and GC, average $305 \mathrm{~g} / \mathrm{d}$ compared with saline), glucose uptake increased only on GC. Recent studies have suggested that AA can contribute to galactose synthesis (Lapierre et al., 2013; Maxin et al., 2013). However, that hypothesis is not supported by the work of Forsberg et al. (1985), who detected no label in lactose when ${ }^{14} \mathrm{C}$-labeled lactate was included in the media of galactogenic mammary tissue slices - that is, the label entering the lower portion of the glycolytic pathway is not transferred to the upper portions of the pathway. It is more likely that glucose oxidized in the pentose phosphate pathway to produce NADPH was reduced, leaving more glucose available for lactose synthesis. The loss in NADPH production with this shift could be replaced through the oxidation of more acetate in the cytosolic isocitrate dehydrogenase pathway (Hanigan and Baldwin, 1994). Several studies have reported that, as the rate of wholebody glucose appearance increases, the ratio of lactose to whole-body glucose appearance decreases (Rigout et al., 2003; Lemosquet et al., 2004, 2009a). This may be a consequence of glucose partitioning away from the mammary gland toward other tissues, due to greater action of insulin with increased glucose, or changes in glucose utilization within the mammary cell (Lemosquet et al., 2009a). Blood lactate concentration was not measured in the present study, and lactate can also be used by the mammary gland as an energy source, sparing glucose to for lactose synthesis.

\section{Effects of Acetate}

As mentioned earlier, mTORC1 coordinates nutritional and endocrinal signals to regulate protein translation in the mammary cell. Besides protein kinase $\mathrm{B}$ (AKT), mTORC1 is under the regulation of AMPK, which is able to sense cellular energy status. When cellular energy levels are low, AMPK is activated by phosphorylation and inhibits processes that consume ATP, such as protein synthesis, which is affected via inhibition of mTORC1, as demonstrated by Burgos et al. (2013) in bovine mammary epithelial cells. Glucose and lactate are the main energy precursors in the mammary cells of monogastric mammals (Larson, 1985). In ruminants, however, due to lower arterial concentrations of glucose and higher concentrations of acetate compared with non-ruminants, a need exists to spare glucose for synthesis of lactose and NADPH, making acetate of greater importance as an energy substrate in ruminant mammary cells (Bickerstaffe et al., 1974). This suggests that acetate could potentially stimulate milk protein synthesis via AMPK inhibition, resulting from higher cellular energy status. Indeed, Safayi and Nielsen (2013) reported a tendency $(P=0.11)$ for increased milk protein yield in response to intravenous infusion of acetate in goats in early lactation. Furthermore, Rook and Balch (1961) observed increased milk protein yield with ruminal infusion of $960 \mathrm{~g} / \mathrm{d}$ of acetate over several days.

In the present study, however, acetate exhibited no effect on yield of milk or milk protein and responded to feed restriction in a manner similar to the negative control. When infused along with casein, effects were similar to those from casein alone, supporting the observation that acetate itself had no effect. The difference between the present results and those reported by Safayi and Nielsen (2013) might be due to site of acetate infusion (abomasal vs. intravenous), which promoted greater differences in arterial acetate concentrations in acetate infusions relative to the saline control ( $45 \%$ vs. $30 \%$ in the present study). Another possibility is that goats responded to acetate infusion with increased milk protein yield only in early lactation (21 DIM), when the mammary gland appears to be more responsive and feed intake often is insufficient to meet the nutritional requirements for milk production. Supporting the lack of an effect, Castro et al. (2016) observed very low responses to acetate when modeling results from a mammary tissue slice system.

Numerically greater mammary acetate uptake for the 2 acetate infusions (treatments $\mathrm{A}$ and $\mathrm{AC}, P<$ 0.12 ), with no changes in acetate clearance rates, suggested that acetate uptake was a direct consequence of arterial acetate concentration, as demonstrated also 
by Purdie et al. (2008). Even though more acetate was taken up by the mammary glands with acetate infusions, it appears to have been used primarily for milk fat synthesis, rather than for energy production, as suggested by the numeric increases in milk fat yield in both acetate infusions. This observation was further supported by the greater mammary glucose uptake with the acetate infusion alone, which would be needed to supply glycerol and NADPH for de novo fatty acid synthesis (Chaiyabutr et al., 2008). In contrast, Purdie et al. (2008) did not report increased milk fat yield with 10-h close arterial acetate infusion, despite $123 \%$ increase in arterial glucose concentration and $128 \%$ increase in mammary acetate uptake.

Despite no increase in milk protein yield and an MP supply similar to that of the negative control, arterial concentrations of NEAA-N were reduced in A relative to $\mathrm{S}$. The reason for the reduced arterial NEAA concentrations in the present study was not greater mammary uptake. No changes in mammary AA metabolism were expected, because no changes were observed in milk protein yield relative to saline, and indeed the 2 acetate treatments behaved similarly.

\section{CONCLUSIONS}

Abomasal infusion of casein and glucose for $5 \mathrm{~d}$ in cows that were $15 \%$ feed-restricted increased milk protein yield by 100 and $165 \mathrm{~g} / \mathrm{d}$, respectively. Recovery of infused casein was $25 \%$, and efficiency of MP utilization for milk protein yield (milk protein yield/predicted total MP supply) was $46 \%$ with the casein infusion. The increase in milk protein yield with glucose infusion was brought about by an increase in mammary clearance rate for all EAA except Thr, overcoming the decreased arterial concentrations of most AA. In addition, glucose infusion increased utilization of circulating NEAA for milk protein synthesis (increased ratio of mammary uptake to milk output), reducing the use of EAA for synthesis of NEAA (decreased uptake-tooutput ratio) and therefore reducing intramammary AA catabolism. These shifts in mammary gland metabolism in response to glucose infusion resulted in an efficiency of MP utilization for milk protein synthesis of $58 \%$. The combination of glucose and casein infusions further increased milk protein yield $(184 \mathrm{~g} / \mathrm{d})$ and almost doubled the recovery of infused casein to $47 \%$. Acetate infusion alone had no effect on milk protein yield but numerically increased milk fat yield, suggesting that the greater amount of acetate taken up by the mammary gland was used for milk fat synthesis rather than ATP production. Infusion of acetate and casein together promoted responses similar to those of casein alone. In conclusion, glucose stimulated milk protein synthesis, and the mammary gland responded by increasing clearance of EAA to match its synthetic capacity. Additionally, these results emphasize the limitations of the NRC (2001) model in predicting the independent metabolic responses to glucose and casein, because it implicitly assumes that a single nutrient is limiting milk protein synthesis at any point in time, whereas the system exhibits a multi-substrate response surface with multiple nutrients potentially limiting production at any time.

\section{ACKNOWLEDGMENTS}

The authors thank the Coordenação de Aperfeiçoamento de Pessoal de Nivel Superior (CAPES, Brasília, Brazil) for partial funding support of MACD; Mike Maroney and Teresa Hirsch of the Research Animal Resources Committee of the University of Wisconsin, Madison, for all veterinary assistance; the barn crew of both the US Dairy Forage Research Center (DFRC, Prairie du Sac, WI) and the University of Wisconsin Dairy Cattle Center (Madison, WI) for feeding and animal care; Wendy Radloff and Mary Becker of the US DFRC for assisting with laboratory analyses and sample collection; the late Jane Marita of the US Dairy Forage Research Center for invaluable assistance with the GCMS analysis; and Helene Lapierre and Jocelyne Renaud, from Agriculture and Agri-Food Canada (Ottawa), for guidance with the AA analysis. The authors have not stated any conflicts of interest.

\section{REFERENCES}

AOAC (Association of Official Analytical Chemists). 1980. Official Methods of Analysis. 13th ed. AOAC, Washington, DC.

AOAC (Association of Official Analytical Chemists). 1990. Official Methods of Analysis. 15th ed. AOAC, Arlington, VA.

Appuhamy, J. A. D. R. N., A. L. Bell, W. A. D. Nayananjalie, J. Escobar, and M. D. Hanigan. 2011. Essential AA regulate both initiation and elongation of mRNA translation independent of insulin in MAC-T cells and bovine mammary tissue slices. J. Nutr. 141:1209-1215. https://doi.org/10.3945/jn.110.136143.

Appuhamy, J. A. D. R. N., N. A. Knoebel, W. A. D. Nayananjalie, J. Escobar, and M. D. Hanigan. 2012. Isoleucine and leucine independently regulate mTOR signaling and protein synthesis in MAC-T cells and bovine mammary tissue slices. J. Nutr. 142:484-491.

Appuhamy, J. A. D. R. N., W. A. Nayananjalie, E. M. England, D. E. Gerrard, R. M. Akers, and M. D. Hanigan. 2014. Effects of AMPactivated protein kinase (AMPK) signaling and essential amino acids on mammalian target of rapamycin (mTOR) signaling and protein synthesis rates in mammary cells. J. Dairy Sci. 97:419-429. https://doi.org/10.3168/jds.2013-7189.

Arriola Apelo, S. I., L. M. Singer, X. Y. Lin, M. L. McGilliard, N. R. St-Pierre, and M. D. Hanigan. 2014. Isoleucine, leucine, methionine, and threonine effects on mammalian target of rapamycin signaling in mammary tissue. J. Dairy Sci. 97:1047-1056. https:// doi.org/10.3168/jds.2013-7348.

Bequette, B. J., M. D. Hanigan, A. G. Calder, C. K. Reynolds, G. E. Lobley, and J. C. MacRae. 2000. Amino acid exchange by the mammary gland of lactating goats when histidine limits milk pro- 
duction. J. Dairy Sci. 83:765-775. https://doi.org/10.3168/jds .S0022-0302(00)74939-3.

Bickerstaffe, R., E. F. Annison, and J. L. Linzell. 1974. Metabolism of glucose, acetate, lipids and amino-acids in lactating dairy-cows. J. Agric. Sci. 82:71-85. https://doi.org/10.1017/S0021859600050243.

Broderick, G. A. 2003. Effects of varying dietary protein and energy levels on the production of lactating dairy cows. J. Dairy Sci. 86:1370-1381. https://doi.org/10.3168/jds.S0022-0302(03)73721 -7 .

Broderick, G. A., and M. K. Clayton. 1997. A statistical evaluation of animal and nutritional factors influencing concentrations of milk urea nitrogen. J. Dairy Sci. 80:2964-2971.

Broderick, G. A., T. Kowalczyk, and L. D. Satter. 1970. Milk production response to supplementation with encapsulated methionine per Os or casein per abomasum. J. Dairy Sci. 53:1714-1721. https: //doi.org/10.3168/jds.S0022-0302(70)86468-2.

Burgos, S. A., J. J. Kim, M. Dai, and J. P. Cant. 2013. Energy depletion of bovine mammary epithelial cells activates AMPK and suppresses protein synthesis through inhibition of mTORC1 signaling. Horm. Metab. Res. 45:183-189. https://doi.org/10.1055/s-0032 -1323742 .

Calder, A. G., K. E. Garden, S. E. Anderson, and G. E. Lobley. 1999 Quantitation of blood and plasma amino acids using isotope dilution electron impact gas chromatography/mass spectrometry with U-13C amino acids as internal standards. Rapid Commun. Mass Spectrom. 13:2080-2083. https://doi.org/10.1002/(SICI)1097 -0231(19991115)13:21<2080::AID-RCM755>3.0.CO;2-O.

Cant, J. P., R. Berthiaume, H. Lapierre, P. H. Luimes, B. W. McBride, and D. Pacheco. 2003. Responses of the bovine mammary glands to absorptive supply of single amino acids. Can. J. Anim. Sci. 83:341-355. https://doi.org/10.4141/A02-077.

Cant, J. P., E. J. DePeters, and R. L. Baldwin. 1993. Mammary amino acid utilization in dairy cows fed fat and its relationship to milk protein depression. J. Dairy Sci. 76:762-774.

Cantalapiedra-Hijar, G., J. L. Peyraud, S. Lemosquet, E. MolinaAlcaide, H. Boudra, P. Nozière, and I. Ortigues-Marty. 2014. Dietary carbohydrate composition modifies the milk $\mathrm{N}$ efficiency in late lactation cows fed low crude protein diets. Animal 8:275-285. https://doi.org/10.1017/S1751731113002012.

Castro, J. J., S. I. Arriola Apelo, J. A. D. R. N. Appuhamy, and M. D. Hanigan. 2016. Development of a model describing regulation of casein synthesis by the mammalian target of rapamycin (mTOR) signaling pathway in response to insulin, amino acids, and acetate. J. Dairy Sci. 99:6714-6736. https://doi.org/10.3168/ jds.2015-10591.

Chaiyabutr, N., S. Komolvanich, S. Thammacharoen, and S. Chanpongsang. 2008. Effects of long-term exogenous bovine somatotropin on glucose metabolism and the utilization of glucose by the mammary gland in different stages of lactation of crossbred Holstein cattle. Anim. Sci. J. 79:561-574. https://doi.org/10.1111/ j.1740-0929.2008.00565.x.

Clark, J. H., H. R. Spires, R. G. Derrig, and M. R. Bennink. 1977. Milk production, nitrogen utilization and glucose synthesis in lactating cows infused postruminally with sodium caseinate and glucose. J. Nutr. 107:631-644. https://doi.org/10.1093/jn/107.4.631.

Doepel, L., and H. Lapierre. 2010. Changes in production and mammary metabolism of dairy cows in response to essential and nonessential amino acid infusions. J. Dairy Sci. 93:3264-3274. https:// doi.org/10.3168/jds.2009-3033.

Doepel, L., D. Pacheco, J. J. Kennelly, M. D. Hanigan, I. F. López, and H. Lapierre. 2004. Milk protein synthesis as a function of amino acid supply. J. Dairy Sci. 87:1279-1297. https://doi.org/10 .3168/jds.S0022-0302(04)73278-6.

Emery, R. S., L. D. Brown, and J. W. Bell. 1965. Correlation of milk fat with dietary and metabolic factors in cows fed restricted roughage rations supplemented with magnesium oxide or sodium bicarbonate. J. Dairy Sci. 48:1647-1651. https://doi.org/10.3168/jds .S0022-0302(65)88543-5.

Forsberg, N. E., R. L. Baldwin, and N. E. Smith. 1985. Roles of lactate and its interactions with acetate in maintenance and biosynthesis in bovine mammary tissue. J. Dairy Sci. 68:2550-2556. https://doi .org/10.3168/jds.S0022-0302(85)81136-X.

Galindo, C. E., D. R. Ouellet, D. Pellerin, S. Lemosquet, I. OrtiguesMarty, and H. Lapierre. 2011. Effect of amino acid or casein supply on whole-body, splanchnic, and mammary glucose kinetics in lactating dairy cows. J. Dairy Sci. 94:5558-5568. https://doi.org/ 10.3168/jds.2010-3978.

Gressley, T. F., S. M. Reynal, J. O. Colmenero, G. A. Broderick, and L. E. Armentano. 2006. Technical note: Development of a tool to insert abomasal infusion lines into dairy cows. J. Dairy Sci. 89:3965-3967. https://doi.org/10.3168/jds.S0022-0302(06)72438 $-9$.

Hanigan, M. D., and R. L. Baldwin. 1994. A mechanistic model of mammary gland metabolism in the lactating cow. Agric. Syst. 45:369-419. https://doi.org/10.1016/0308-521X(94)90132-Y.

Hanigan, M. D., J. P. Cant, D. C. Weakley, and J. L. Beckett. 1998a. An evaluation of postabsorptive protein and amino acid metabolism in the lactating dairy cow. J. Dairy Sci. 81:3385-3401. https: //doi.org/10.3168/jds.S0022-0302(98)75903-X.

Hanigan, M. D., L. A. Crompton, J. A. Metcalf, and J. France. 2001. Modelling mammary metabolism in the dairy cow to predict milk constituent yield, with emphasis on amino acid metabolism and milk protein production: Model construction. J. Theor. Biol. 213:223-239. https://doi.org/10.1006/jtbi.2001.2417.

Hanigan, M. D., L. A. Crompton, C. K. Reynolds, D. Wray-Cahen, M. A. Lomax, and J. France. 2004. An integrative model of amino acid metabolism in the liver of the lactating dairy cow. J. Theor. Biol. 228:271-289. https://doi.org/10.1016/j.jtbi.2004.01.010.

Hanigan, M. D., J. France, L. A. Crompton, and B. J. Bequette. 2000. Evaluation of a representation of the limiting amino acid theory for milk protein synthesis. Pages 127-144 in Modelling Nutrient Utilization in Farm Animals. J. P. McNamara, J. France, and D. E. Beever, ed. CABI, Wallingford, UK.

Hanigan, M. D., J. France, D. Wray-cahen, D. E. Beever, G. E. Lobley, L. Reutzel, and N. E. Smith. 1998b. Alternative models for analyses of liver and mammary transorgan metabolite extraction data. Br. J. Nutr. 79:63-78. https://doi.org/10.1079/BJN19980010.

Haque, M. N., J. Guinard-Flament, P. Lamberton, C. Mustière, and S. Lemosquet. 2015. Changes in mammary metabolism in response to the provision of an ideal amino acid profile at 2 levels of metabolizable protein supply in dairy cows: Consequences on efficiency. J. Dairy Sci. 98:3951-3968. https://doi.org/10.3168/jds.2014-8656.

Hintz, R. W., D. R. Mertens, and K. A. Albrecht. 1996. Effects of sodium sulfite on recovery and composition of detergent fiber and lignin. J. AOAC Int. 79:16-22. https://doi.org/10.1093/jaoac/79 .1 .16

Hundal, H. S., and P. M. Taylor. 2009. Amino acid transceptors: Gate keepers of nutrient exchange and regulators of nutrient signaling. Am. J. Physiol. Endocrinol. Metab. 296:E603-E613. https://doi .org/10.1152/ajpendo.91002.2008.

Hurtaud, C., S. Lemosquet, and H. Rulquin. 2000. Effect of graded duodenal infusions of glucose on yield and composition of milk from dairy cows. 2. Diets based on grass silage. J. Dairy Sci. 83:29522962. https://doi.org/10.3168/jds.S0022-0302(00)75195-2.

Karkalas, J. J. 1985. An improved enzymatic method for the determination of native and modified starch. J. Sci. Food Agric. 36:1019 1027. https://doi.org/10.1002/jsfa.2740361018.

Krause, K. M., D. K. Combs, and K. A. Beauchemin. 2003. Effects of increasing levels of refined cornstarch in the diet of lactating dairy cows on performance and ruminal pH. J. Dairy Sci. 86:1341-1353. https://doi.org/10.3168/jds.S0022-0302(03)73719-9.

Lapierre, H., R. Berthiaume, G. Raggio, M. C. Thivierge, L. Doepel, D. Pacheco, P. Dubreuil, and G. E. Lobley. 2005. The route of absorbed nitrogen into milk protein. Anim. Sci. 80:11-22. https:// doi.org/10.1079/ASC41330011.

Lapierre, H., S. Lemosquet, and D. R. Ouellet. 2013. Contribution of essential amino acids to glucose metabolism and lactose secretion in late lactation dairy cows. Pages 447-448 in Energy and Protein Metabolism and Nutrition in Sustainable Animal Production, EAAP publication No. 134. J. W. Oltjen, E. Kebreab, and H. Lapierre, ed. Wageningen Academic Publishers, the Netherlands. 
Lapierre, H., G. E. Lobley, L. Doepel, G. Raggio, H. Rulquin, and S. Lemosquet. 2012. Triennial Lactation Symposium: Mammary metabolism of amino acids in dairy cows. J. Anim. Sci. 90:1708-1721. https://doi.org/10.2527/jas.2011-4645.

Larson, B. L. 1985. Lactation. Iowa State University Press, Ames, IA. Lemosquet, S., E. Delamaire, H. Lapierre, J. W. Blum, and J. L. Peyraud. 2009a. Effects of glucose, propionic acid, and nonessential amino acids on glucose metabolism and milk yield in Holstein dairy cows. J. Dairy Sci. 92:3244-3257. https://doi.org/10.3168/ jds.2008-1610.

Lemosquet, S., G. E. Lobley, R. Koopman, L. J. C. van Loon, A. K. Kies, and H. Lapierre. 2010. A large supply of phenylalanine is not oxidised by the mammary gland of dairy cows. Pages 139-140 in Energy and Protein Metabolism and Nutrition, EAAP Publication No. 127. C. M. Crovetto, ed. Wageningen Academic Publishers, Wageningen, the Netherlands.

Lemosquet, S., G. Raggio, G. E. Lobley, H. Rulquin, J. Guinard-Flament, and H. Lapierre. 2009b. Whole-body glucose metabolism and mammary energetic nutrient metabolism in lactating dairy cows receiving digestive infusions of casein and propionic acid. J. Dairy Sci. 92:6068-6082. https://doi.org/10.3168/jds.2009-2018.

Lemosquet, S., S. Rigout, A. Bach, H. Rulquin, and J. W. Blum. 2004 Glucose metabolism in lactating dairy cows in response to isoenergetic infusions of propionic acid or duodenal glucose. J. Dairy Sci. 87:1767-1777. https://doi.org/10.3168/jds.S0022-0302(04)73332 $-9$.

Licitra, G., T. M. Hernandez, and P. J. Van Soest. 1996. Standardization of procedures for nitrogen fractionation of ruminant feeds. Anim. Feed Sci. Technol. 57:347-358. https://doi.org/10.1016/ 0377-8401(95)00837-3.

Lobley, G. E. 1990. Energy metabolism reactions in ruminant muscle: Responses to age, nutrition, and hormonal status. Reprod. Nutr. Dev. 30:13-34. https://doi.org/10.1051/rnd:19900102.

Maas, J. A., J. P. Cant, B. W. McBride, D. R. Trout, and D. P. Poppi. 1995. Method for close arterial infusion of the lactating mammary gland. Can. J. Anim. Sci. 75:345-349. https://doi.org/10.4141/ cjas95-053.

Mackle, T. R., D. A. Dwyer, K. L. Ingvartsen, P. Y. Chouinard, J. M. Lynch, D. M. Barbano, and D. E. Bauman. 1999. Effects of insulin and amino acids on milk protein concentration and yield from dairy cows. J. Dairy Sci. 82:1512-1524. https://doi.org/10.3168/ jds.S0022-0302(99)75378-6.

Maxin, G., D. R. Ouellet, and H. Lapierre. 2013. Contribution of amino acids to glucose and lactose synthesis in lactating dairy cows. Pages 447-448 Energy and Protein Metabolism and Nutrition in Sustainable Animal Production. EAAP publication no. 134. J. W. Oltjen, E. Kebreab, and H. Lapierre, ed. Wageningen Academic Publishers, Wageningen, the Netherlands.

NRC (National Research Council). 2001. Nutrient Requirements of Dairy Cattle. 7th ed. Natl. Acad. Press, Washington, DC.

Purdie, N. G., D. R. Trout, D. P. Poppi, and J. P. Cant. 2008. Milk synthetic response of the bovine mammary gland to an increase in the local concentration of amino acids and acetate. J. Dairy Sci. 91:218-228. https://doi.org/10.3168/jds.2007-0492.

Raggio, G., S. Lemosquet, G. E. Lobley, H. Rulquin, and H. Lapierre. 2006. Effect of casein and propionate supply on mammary protein metabolism in lactating dairy cows. J. Dairy Sci. 89:4340-4351. https://doi.org/10.3168/jds.S0022-0302(06)72481-X.

Rigout, S., C. Hurtaud, S. Lemosquet, A. Bach, and H. Rulquin. 2003. Lactational effect of propionic acid and duodenal glucose in cows. J. Dairy Sci. 86:243-253.

Rius, A. G., J. A. D. R. N. Appuhamy, J. Cyriac, D. Kirovski, O. Becvar, J. Escobar, M. L. McGilliard, B. J. Bequette, R. M. Akers, and M. D. Hanigan. 2010a. Regulation of protein synthesis in mammary glands of lactating dairy cows by starch and amino acids. J. Dairy Sci. 93:3114-3127. https://doi.org/10.3168/jds.2009 -2743 .

Rius, A. G., M. L. McGilliard, C. Umberger, and M. D. Hanigan. 2010b. Interactions of energy and predicted metabolizable protein in determining nitrogen efficiency in the lactating dairy cow. J. Dairy Sci. 93:2034-2043. https://doi.org/10.3168/jds.2008-1777.

Rook, J. A., and C. C. Balch. 1961. Effects of intraruminal infusions of acetic, propionic and butyric acids on yield and composition of milk of cow. Br. J. Nutr. 15:361-369. https://doi.org/10.1079/ BJN19610046.

Rulquin, H., S. Rigout, S. Lemosquet, and A. Bach. 2004. Infusion of glucose directs circulating amino acids to the mammary gland in well-fed dairy cows. J. Dairy Sci. 87:340-349. https://doi.org/10 .3168/jds.S0022-0302(04)73173-2.

Safayi, S., and M. O. Nielsen. 2013. Intravenous supplementation of acetate, glucose or essential amino acids to an energy and protein deficient diet in lactating dairy goats: Effects on milk production and mammary nutrient extraction. Small Rumin. Res. 112:162173. https://doi.org/10.1016/j.smallrumres.2012.12.001.

Sheperd, A. C., and D. K. Combs. 1998. Long-term effects of acetate and propionate on voluntary feed intake by midlactation cows. J. Dairy Sci. 81:2240-2250. https://doi.org/10.3168/jds.S0022 $-0302(98) 75803-5$.

Toerien, C. A., D. R. Trout, and J. P. Cant. 2010. Nutritional stimulation of milk protein yield of cows is associated with changes in phosphorylation of mammary eukaryotic initiation factor 2 and ribosomal S6 kinase 1. J. Nutr. 140:285-292. https://doi.org/10 $.3945 /$ jn.109.114033.

Tyrrell, H. F., and J. T. Reid. 1965. Prediction of the energy value of cow's milk. J. Dairy Sci. 48:1215-1223. https://doi.org/10.3168/ jds.S0022-0302(65)88430-2.

Van Soest, P. J., J. B. Robertson, and B. A. Lewis. 1991. Methods for dietary fiber, neutral detergent fiber, and nonstarch polysaccharides in relation to animal nutrition. J. Dairy Sci. 74:3583-3597. https://doi.org/10.3168/jds.S0022-0302(91)78551-2.

Vanhatalo, A., T. Varvikko, and P. Huhtanen. 2003. Effects of casein and glucose on responses of cows fed diets based on restrictively fermented grass silage. J. Dairy Sci. 86:3260-3270. https://doi .org/10.3168/jds.S0022-0302(03)73929-0.

Vik-Mo, L., R. S. Emery, and J. T. Huber. 1974. Milk protein production in cows abomasally infused with casein or glucose. J. Dairy Sci. 57:869-877. https://doi.org/10.3168/jds.S0022-0302(74)84979 $-9$.

Whitelaw, F. G., J. S. Milne, E. R. Orskov, and J. S. Smith. 1986. The nitrogen and energy metabolism of lactating cows given abomasal infusions of casein. Br. J. Nutr. 55:537-556. https://doi.org/10 $.1079 /$ BJN19860061.

Yoder, P. S., X. Huang, I. A. Teixeira, J. P. Cant, and M. D. Hanigan. 2020. Effects of jugular infused methionine, lysine, and histidine as a group or leucine and isoleucine as a group on production and metabolism in lactating dairy cows. J. Dairy Sci. 103:2387-2404. https://doi.org/10.3168/jds.2019-17082.

\section{ORCIDS}

M. A. C. Danes () https://orcid.org/0000-0003-4196-8328 M. D. Hanigan ๑ https://orcid.org/0000-0002-5639-9677 S. I. Arriola Apelo @ https://orcid.org/0000-0003-0274-5367 J. D. L. Dias (๑ https://orcid.org/0000-0003-2933-7953 M. A. Wattiaux @ https://orcid.org/0000-0001-8713-1641 G. A. Broderick @ https://orcid.org/0000-0002-3466-9728 